This is an Accepted Manuscript of an article published by Taylor \& Francis Group in Journal of Private International Law on 5 Aug 2016, available online http://www.tandfonline.com/10.1080/17441048.2016.1206708

\title{
Conflicts of EU courts on child abduction: the reality of Article 11(6)-(8) Brussels IIa proceedings across the $\mathbf{E U}$
}

This article contains the final findings from a research project funded by the Nuffield Foundation and conducted by the authors on "Conflicts of EU Courts on Child Abduction". Such "conflicts" were deliberately created by the EU legislature when it created a power in Article 11(6)-(8) of the Brussels IIa Regulation for the courts of the habitual residence to insist on the return of a child that has been abducted after a court in the State where the child was abducted to has refused to return the child on the basis of one of the exceptions to the duty to return provided for in Article 13 of the Hague Child Abduction Convention 1980. It will reveal how infrequently used and largely ineffective the Article 11(6)-(8) system is and will make proposals for law reform in the current revision of the Brussels IIa Regulation.

Keywords: international family law; child abduction; intra-EU cases; Brussels IIa Regulation; Hague Child Abduction Convention; gender of abducting parent; right of a child to be heard; right of parents to be heard; grave risk of harm; child's objections to return; consent; acquiescence.

\section{A. Introduction}

This article investigates child abduction in the EU under the Brussels IIa Regulation (hereafter "Brussels IIa"). ${ }^{1}$ In particular the article looks at the procedure under Article 11(6)-(8) which applies following an Article 13 Hague Child Abduction Convention (hereafter "Hague") nonreturn order in the State of refuge. ${ }^{2}$ This procedure is of particular interest because it reinforces the jurisdiction of the State of the child's habitual residence in child abduction cases, it was added when the Brussels II Regulation was last revised and became Brussels IIa and there is limited data on these proceedings. The decisions arising from this process are in a different class from most other decisions on parental responsibility made under Brussels IIa as they are automatically enforceable when accompanied by an Article 42 certificate. ${ }^{3}$ The court in the state of refuge is not allowed to review the decision nor the certificate. ${ }^{4}$ The system is underpinned by the EU principle of 'mutual trust'. 5 This article investigates how these

\footnotetext{
${ }^{1}$ Council Regulation (EC) No 2201/2003 of 27 November 2003 concerning jurisdiction and the recognition and enforcement of judgments in matrimonial matters and the matters of parental responsibility, repealing Regulation (EC) No 1347/2000 [2003] OJ L338/1.

${ }^{2}$ Hague Convention of 25 October 1980 on the Civil Aspects of International Child Abduction. See https://www.hcch.net/en/instruments/conventions/specialised-sections/child-abduction accessed 12 January 2016.

${ }^{3}$ Arts 11(8) and 42 Brussels IIa. Decisions on access are also automatically enforceable under Art 41.

${ }^{4}$ See Case C-491/10 PPU Aguirre Zarraga v Pelz [2010] ECR I-14247, and Art 43 Brussels IIa.

${ }^{5}$ Recital 21, Brussels IIa and see Case C-491/10 PPU Aguirre Zarraga v Pelz [2010] ECR I-14247 paras 46 and 70. On the other hand "mutual trust" may not be shown by the operation of Art 11(6)-(8) Brussels IIa when the
} 
proceedings are being carried out throughout the EU, looking specifically at: the nature of the order, the implementation of the order, whether the parties are being heard and the validity of the Article 42 certificate, in order to critically assess the viability of the procedure in its current form. This research is timely given the ongoing review of Brussels IIa. The opportunity will be taken to make proposals for reform of Brussels IIa in the light of the research findings.

\section{B. Methodology}

Data was collected from a variety of sources across the duration of the project. The project sought to collect data on cases where there were Article 11(6)-(8) Brussels IIa proceedings arising from Article 13 Hague non-return orders made between 1 March 2005 and 28 February 2014. The findings include systematic data on these cases recovered from all sources. ${ }^{6}$ However as it was difficult to trace Article 11(8) cases all the information received is included, therefore there are two cases included where the Article 13 non-return order was given after 28 February 2014, and there were Article 11(8) proceedings. $^{7}$ Initially a questionnaire was sent to each of the Central Authorities. ${ }^{8}$ However as these proceedings do not need to go through the Central Authority, we could not rely substantially on the information provided by the Central Authorities which was not comprehensive. Other factors also hindered the ability of the Central Authorities to supply data, these were lack of human resources, lack of a comprehensive database or in some cases such as Greece, any form of computerised database at all. In addition to sending the questionnaire to Central Authorities a local researcher provided information on their Member State, and questionnaires were also circulated to Hague network judges,

courts of the child's habitual residence override the non-return order of a fellow EU court made under Art 13 Hague.

${ }^{6}$ The initial questionnaire sent to the Central Authorities sought to recover data on all cases within this time frame. The tables include data provided to us up until 30 September 2015. Some interviews were carried out after this, where we received interesting information on the procedure but no concrete information on additional cases.

${ }^{7}$ Latvian CA ref no: No.25-1.28/13 and Italian CA ref no: 158/13. It is unlikely that these are the only cases beyond the initial period (see below) because data was not collected systematically beyond the initial period. The Latvian Central Authority did not provide the information until later than many of the Central Authorities so it covers a longer period, and we went back to the Italian Central Authority on three pending cases, one of which fell outside the initial period. For further information please see the Latvian and Italian sections of the Country Reports available at the project website, https://www.abdn.ac.uk/law/research/conflicts-of-eu-courtson-child-abduction-417.php accessed 20 May 2016. There are some potential Art 11(8) cases currently ongoing in the Netherlands. There are some ongoing English cases, one involving Estonia, one with Poland and the other involving Bulgaria. There is also an English Polish case that has just been concluded, where the English court held that the child could remain in Poland (information provided during interviews and networking).

${ }^{8}$ See P Beaumont, L Walker and J Holliday, "Not Heard and Not Returned: The reality of Article 11(8) proceedings" [2015] International Family Law 124, for an analysis of the initial information sent by Central Authorities. 
practitioners and relevant NGOs. The combined information indicates that our overall findings broadly reflect the preliminary findings based solely on the information provided by the Central Authorities. ${ }^{9}$ The quantitative findings were analysed through the SPSS system. In addition to the collection of quantitative data interviews were carried out with judges and practitioners in five selected Member States in order to gain further information on those States and identify any practical issues that arose when applying the Regulation in Member States, and follow up on information gathered through cases files. These States were: Belgium, Latvia, The Netherlands, Portugal and the UK (predominantly England and Wales). ${ }^{10}$ These States were chosen primarily because of the number of proceedings, however we also took account of geographical location (Latvia), and States which had interesting proceedings with other Member States (Portugal). Various attempts were made to carry out interviews in Italy but unfortunately this was not possible.

\section{Findings}

\section{General findings on Article 11(6)-(8) Brussels IIa}

The findings indicate that there were at least 66 applications, concerning 70 children, which involved Article 11(6)-(8) Brussels IIa proceedings since the date of entry into force of Brussels IIa until June 2015. ${ }^{11}$ The consolidated information indicates that the Article 11(6)-(8) proceedings were distributed as follows:

\begin{tabular}{|l|r|}
\hline Member State & $\begin{array}{c}\text { Number of } \\
\text { Article 11(6)- } \\
(8) \\
\text { proceedings }\end{array}$ \\
\hline Austria & 1 \\
Belgium & 7 \\
Bulgaria & 0 \\
Croatia & 0 \\
Cyprus & 0 \\
Czech Republic & 1 \\
Estonia & 0 \\
Finland & 0 \\
France & 2
\end{tabular}

\footnotetext{
${ }^{9}$ Ibid.

${ }^{10}$ A pilot study was carried out in The Netherlands, followed by a re-interview near the end of the project.

${ }^{11} 63$ is the number of cases that were identified during the course of the study, it is very likely that there are more cases than this. Where the finding is 0 in some cases this is because there are genuinely no cases (such as Croatia, which has only been a Member State since 2013) and in other cases this is because no cases were found by any of our contacts. For further details please see the Country Reports, supra $\mathrm{n} 7$.
} 


\begin{tabular}{|l|r|}
\hline Germany & 6 \\
Greece & 1 \\
Hungary & 1 \\
Ireland & 5 \\
Italy & 17 \\
Latvia & 1 \\
Lithuania & 0 \\
Luxembourg & 1 \\
Malta & 0 \\
Netherlands & 0 \\
Poland & 0 \\
Portugal & 3 \\
Romania & 5 \\
Slovakia & 0 \\
Slovenia & 1 \\
Spain & 3 \\
Sweden & 0 \\
UK & 11 \\
Total & $\mathbf{6 6}$ \\
\hline
\end{tabular}

Figure 1: Number of Article 11(6)-(8) proceedings

It is slightly strange that the vast majority of cases, 91 per cent, involved only one child. The official figures from 2008 showed that more than one child was involved in 31 per cent of Hague cases. ${ }^{12}$ Kruger's findings show that abductions occur more often in small families, which she suggests makes sense from a logistical point of view, as it is much easier to organise the abduction of a single child. ${ }^{13}$ In the present study around half of the children were six years old and under, ${ }^{14}$ and in the majority of cases the abducting parent was returning to the State of their nationality with the child. The majority of abducting parents were female, with 83 per cent of cases where the abducting parent was the mother. In one case the abductions were carried out by the aunt, ${ }^{15}$ in the other cases the findings show that the abductions were carried out by the child's mother or father.

This finding of 83 per cent of abductions being by the mother is much higher than in other studies. In Kruger's study her overall finding was that 65.2 per cent of abductors were female. Broken down this results in 61.9 per cent in abductions from Belgium (67.9 per cent for intraEU cases), and 71.8 per cent for abductions to Belgium (72.2 per cent for intra-EU). ${ }^{16}$

\footnotetext{
${ }^{12}$ See N Lowe and V Stephens, "Global Trends in the Operation of the 1980 Hague Abduction Convention" (2012) Family Law Quarterly 41, 44 (69\% in 2008). This article gives the findings of an official study on Hague Child Abduction Convention proceedings in 2008.

${ }^{13}$ T Kruger, International Child Abduction: The Inadequacies of the Law (Hart Publishing, 2011) 49-50 where a single child was taken in $60 \%$ of the cases she looked at in her study, which concerned abductions to and from Belgium.

${ }^{14}$ For further information see section D. 1 below.

${ }^{15} X v Y$ (2009), where the children spent a long time in Poland with the maternal family before the father issued proceedings for their return (for further information see the Belgian report).

${ }^{16} \mathrm{~T}$ Kruger, supra n 13, 75-79.
} 
Trimmings found that in 2005/06 the abducting party was female in 75 per cent of cases. ${ }^{17}$ Therefore the current findings may indicate an increase in female abductors in recent years, however it is recognised that the present study looks only at specific cases, rather than all abduction applications. The findings could be a sign that the court in the State of refuge is more likely to issue a non-return order where the abducting parent is the mother. This hypothesis is consistent with the findings of the 2008 study where 17 per cent of applications for return were refused where the mother was the abductor, and only 11 per cent where the abductor was the father. In relation to Article 13(1)(b) Hague specifically, return was refused where the mother was the abductor in 30 per cent of cases and only 15 per cent where the abducting parent was the father. ${ }^{18}$ An alternative theory, that may also play a part, is that mothers are likely to have less financial stability than fathers so they might not have the resources available to begin Article 11(6)-(8) Brussels IIa proceedings as legal aid is unlikely to be available. ${ }^{19}$

\section{Article 13 Hague refusals that resulted in Article 11(6)-(8) Brussels IIa proceedings}

A key finding is that in half the cases that resulted in Article 11(6)-(8) Brussels IIa proceedings the non-return was ordered on the basis of Article 13(1)(b) Hague grave risk of harm. ${ }^{20}$ Of these 32 cases the abducting parent was the mother in 30 . There were a further seven cases where the non-return was ordered on the basis of grave risk, combined with the child's objections, ${ }^{21}$ and two cases where it was combined with one of the provisions in Article 13(1)(a).

\footnotetext{
${ }^{17}$ K Trimmings, Child Abduction within the European Union (Hart Publishing, 2013) 79. This study looks only at intra-EU abduction applications made under Brussels IIa.

${ }^{18}$ N Lowe and V Stephens, supra n 12, 63. However cf Lowe and Stephens' findings on Art 13(2) Hague where the opposite is the case.

${ }^{19}$ For more information on legal aid in this context, see below at Section E, 2.

${ }^{20}$ Hague Convention of 1980 on the Civil Aspects of International Child Abduction, Art 13(1)(b).

${ }^{21}$ Ibid, Arts 13(1)(b) and 13(2).
} 


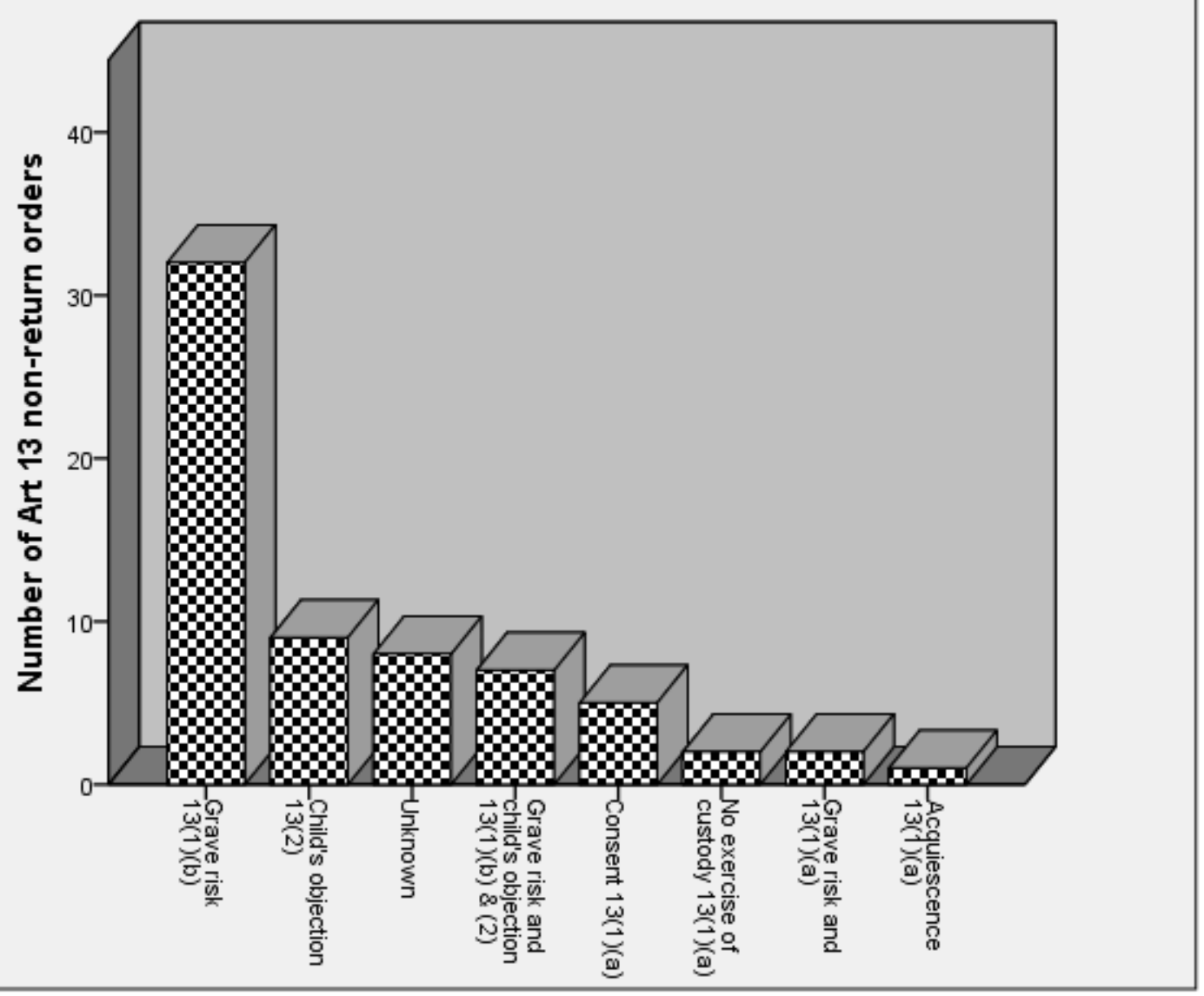

Figure 2: reason for Article 13 refusal

Therefore, there are 41 cases out of 66 where Article 13(1)(b) was given as a whole or partial reason for non-return.

In the other studies on child abduction, ${ }^{22}$ data on judicial refusals cover all reasons that a judge can rely on to refuse return including, lack of habitual residence, lack of custody rights, ${ }^{23}$ the child has settled in their new environment and more than one year had elapsed after the abduction before the return proceedings were instituted ${ }^{24}$ and that the return would be in breach of fundamental rights. ${ }^{25}$ Therefore the information is not necessarily comparable. It is also recognised that the current study only looks at Article 13 Hague non-returns that have developed into Article 11(6)-(8) Brussels IIa proceedings, rather than all Article 13 Hague nonreturns across the EU. ${ }^{26}$ However, where quantities for each of the judicial refusals are given,

\footnotetext{
${ }^{22}$ N Lowe $(1999,2003,2008)$ see for example N Lowe and V Stephens, supra n 12, 41 and K Trimmings, supra n 17.

${ }^{23}$ Both precursors for the operation of the Convention, Arts 3 and 4.

${ }^{24}$ Art 12(2).

${ }^{25}$ Art 20.

${ }^{26}$ The aim was to collect statistics on all Art 13 Hague non-returns so that we could determine how many of these resulted in Art 11 (6)-(8) Brussels IIa proceedings, however we were unable to collect this information
} 
new percentages have been given in order to generate some comparative data. In Trimming's intra-EU study, Article 13(1)(b) refusals accounted for 54 per cent of Article 13 refusals so slightly above that found in the present study. ${ }^{27}$ In the 2008 global study 48 per cent of the Article 13 judicial refusals were based on Article 13(1)(b), which is just below the current finding of 49.2 per cent. ${ }^{28}$ Lowe and Stephens suggest that the steep rise in Article 13(1)(b) refusals is a European phenomenon, and refer particularly to Poland. ${ }^{29}$ Our findings suggest that this is a general trend not restricted to Poland.

\begin{tabular}{|c|c|c|c|c|c|c|c|c|c|}
\hline \multirow[b]{2}{*}{ State of Refuge } & \multicolumn{8}{|c|}{ Reason for Article 13 non-return } & \multirow[t]{2}{*}{ Total } \\
\hline & $\begin{array}{l}\text { Consent } \\
13(1)(a)\end{array}$ & $\begin{array}{c}\text { Acquie- } \\
\text { scence } \\
13(1)(a)\end{array}$ & $\begin{array}{c}\text { Grave } \\
\text { risk } \\
13(1)(b)\end{array}$ & $\begin{array}{c}\text { Child's } \\
\text { objection } \\
13(2)\end{array}$ & $\begin{array}{c}\text { Grave risk } \\
\text { and child's } \\
\text { objection } \\
\text { 13(1)(b) and } \\
13(2)\end{array}$ & $\begin{array}{c}\text { Grave } \\
\text { risk and } \\
13(1)(a)\end{array}$ & $\begin{array}{c}\text { No } \\
\text { exercise of } \\
\text { custody } \\
13(1)(a)\end{array}$ & Unknown & \\
\hline Austria & 0 & 0 & 2 & 1 & $\mathbf{0}$ & $\mathbf{0}$ & 0 & 0 & 3 \\
\hline Belgium & 0 & 0 & 1 & 0 & $\mathbf{0}$ & $\mathbf{0}$ & 1 & 0 & 2 \\
\hline Bulgaria & 0 & 0 & $\mathbf{0}$ & 0 & 1 & $\mathbf{0}$ & 0 & 1 & 2 \\
\hline France & 1 & 0 & 2 & 1 & 1 & 1 & 0 & 0 & 6 \\
\hline Germany & 1 & 0 & 1 & 2 & $\mathbf{0}$ & $\mathbf{0}$ & 0 & 0 & 4 \\
\hline Hungary & 0 & 0 & 1 & 0 & $\mathbf{0}$ & $\mathbf{0}$ & 0 & 0 & 1 \\
\hline
\end{tabular}

across the Member States due to a poor return from Central Authorities; and the collection of this data over the entire period went beyond what we could ask of the independent researcher in each Member State, who kindly assisted us by locating Art 11(6)-(8) proceedings. Unpublished data provided to us by the European Commission on Art 11(6) transmissions that went through Central Authorities (Art 11(6) provides that all documents must be transmitted to the State of origin following an Art 13 Hague non-return order, but these can be sent directly to the Court) suggests that there were at least 31 Art 13 non-return orders in 2014, 49 in 2013 and 64 in 2012; indicating a possible decrease in Art 13 non-return orders, compared to a slight increase in abduction applications (821 (2012), 898 (2013) and 885 (2014). However the data provided by the Commission is incomplete as not all Member States responded. Despite this, the information suggests that there was a possibility to initiate Art 11(7) or (8) proceedings (so there was an Article 13 refusal) in at least 144 cases from 2012-14. Where information was provided by Central Authorities it was as follows: Belgium 1 Article 13 nonreturn order (between 2011-13, this does not correspond with the information provided by the Commission), Bulgaria 34 (since 2007), Cyprus 1, Czech Republic 1 (2010-14), Estonia 1, France 55, Germany 45 (response indicates that there could be more), Hungary 18 (2010-12), Italy 34, Luxembourg 4 (2010-14), Malta 3 , Northern Ireland 2 (since 2011), Latvia 11, Poland 4 (although 5 cases are then listed later in the questionnaire), Romania 11 (since 2007). A search of the English case law suggests that there were 15 reported cases that resulted in an Art 13 Hague non-return between 1 March 2005 and 28 February 2014. Given the lack of consistency between the information provided we cannot use this information to determine how many Art 13 non-return orders there were within the timeframe. Therefore the tables only include information on the cases that resulted in Art 11(6)-(8) proceedings.

${ }^{27} \mathrm{~K}$ Trimmings, supra n $17,90$.

${ }^{28} \mathrm{~N}$ Lowe and V Stephens, supra $\mathrm{n} 12,61$.

${ }^{29} \mathrm{~N}$ Lowe and V Stephens, ibid, 61. 


\begin{tabular}{|c|c|c|c|c|c|c|c|c|c|}
\hline Ireland & 0 & 0 & 1 & 0 & $\mathbf{0}$ & 0 & 0 & 0 & 1 \\
\hline Italy & 0 & 0 & 1 & 0 & $\mathbf{0}$ & $\mathbf{0}$ & 0 & 0 & 1 \\
\hline Latvia & 1 & 0 & 4 & 0 & 1 & $\mathbf{0}$ & 0 & 0 & 6 \\
\hline Lithuania & 0 & 0 & 2 & 1 & $\mathbf{0}$ & $\mathbf{0}$ & 0 & 0 & 3 \\
\hline Malta & 0 & 0 & 1 & 0 & $\mathbf{0}$ & $\mathbf{0}$ & 0 & 0 & 1 \\
\hline Poland & 0 & 0 & 4 & 0 & 1 & $\mathbf{0}$ & 0 & 3 & 8 \\
\hline Portugal & 0 & 0 & 2 & 0 & 1 & $\mathbf{0}$ & 0 & 1 & 4 \\
\hline Romania & 1 & 0 & $\mathbf{0}$ & 1 & $\mathbf{0}$ & $\mathbf{0}$ & 0 & 0 & 2 \\
\hline Slovenia & 0 & 1 & $\mathbf{0}$ & 1 & $\mathbf{0}$ & $\mathbf{0}$ & 0 & 2 & 4 \\
\hline Spain & 0 & 0 & 2 & 0 & $\mathbf{0}$ & $\mathbf{0}$ & 1 & 1 & 4 \\
\hline Sweden & 0 & 0 & $\mathbf{0}$ & 1 & $\mathbf{0}$ & $\mathbf{0}$ & 0 & 0 & 1 \\
\hline UK-England \& Wales & 1 & 0 & 1 & 0 & $\mathbf{0}$ & $\mathbf{0}$ & 0 & 0 & 2 \\
\hline UK-Northern Ireland & 0 & 0 & $\mathbf{0}$ & 0 & 1 & $\mathbf{0}$ & 0 & 0 & 1 \\
\hline Unknown & 0 & 0 & 7 & 1 & 1 & 1 & 0 & 0 & 10 \\
\hline Total & 5 & 1 & 32 & 9 & 7 & 2 & 2 & 8 & 66 \\
\hline
\end{tabular}

Figure 3: reason for non-return by Member State

The Polish courts did issue a number of Article 13(1)(b) non-returns but when Poland is excluded Article 13(1)(b) refusals still equate to 48 per cent of Article 13 refusals so the Polish decisions do not significantly skew the results (although it is noted there are seven cases where the Member State is unknown and these could relate to Poland). This, possible, over-reliance on Article 13(1)(b) is in contention with the aims of the Regulation. ${ }^{30} \mathrm{~A}$, potentially, positive element of Brussels IIa is the introduction of Article 11(4) to abduction proceedings. ${ }^{31}$ Article 11(4) provides that a court 'cannot refuse to return a child on the basis of Article 13(1)(b) of the 1980 Hague Convention if it is established that adequate arrangements have been made to secure the protection of the child after his or her return. ${ }^{32}$ The provision, if used properly, should encourage a dialogue between judges and officials in the two Member States in order to ensure suitable protective measures are in place, where necessary. The proper use of this provision should also assist with the building of mutual trust between Member States, a key principle underlying the Regulation, and allow authorities to build an understanding of suitable mechanisms available in each Member State. Unfortunately, however, our study shows that this provision is not being used adequately by judges in Member States when applying the

\footnotetext{
${ }^{30}$ See K Trimmings, supra $\mathrm{n} 17,50-59$ who suggests that there is not an overuse of Art 13(1)(b), when referring to the findings of the earlier studies.

${ }^{31} \mathrm{~K}$ Trimmings, ibid, 139-155 indicates that Art 11(4) has flaws and argues that it is not clear enough to be useful.

${ }^{32}$ Brussels IIa, Art 11(4).
} 
Article 13(1)(b) exception. This is clear from the Article 11(8) Brussels IIa cases where it is often suggested that the judge in the State of refuge did not take account of Article 11(4). ${ }^{33}$

One downside to Article 11(4) Brussels IIa could be that it only refers to the protection of the child, and not the protection of the abducting parent who is usually the mother. One of the key issues facing judges in the State of refuge is allegations of domestic violence. If the mother is at risk of domestic violence then it will be difficult for her to return with the child if protective measures are not in place. Where the child is young then it is often difficult to return the child without their mother when there are concerns about possible domestic violence by the left-behind parent.

Article 20 Brussels IIa preserves for the courts in "urgent cases" the powers that they have under their national law to take "provisional, including protective, measures in respect of persons or assets in that State". This Article has been given a very restrictive application by the CJEU. $^{34}$

Under Article 11 of the 1996 Convention $^{35}$ a court that is deciding whether to order a return of an abducted child in cases where that child might be at a grave risk of harm or might otherwise be placed in an intolerable situation if returned to the country of the child's habitual residence without any safeguards, can take the "urgent" step of ordering "necessary" protective measures. These could include that the left-behind parent cannot see the child alone and perhaps only with the supervision of a public authority. Such an "urgent" measure has the advantage that it will be recognised by operation of law in the State where the child is being returned to ${ }^{36}$ but will lapse "as soon as the authorities" in the State of the child's habitual residence "have taken the measures required by the situation". ${ }^{37}$ The 1996 Convention improves upon the system of mutual trust that exists under the 1980 Convention whereby

\footnotetext{
${ }^{33}$ See for example, Bradbrooke v Aleksandrowicz R.G. $\mathrm{N}^{\circ}: 2014 / \mathrm{JR} / 73$ et $\mathrm{N}^{\circ}: 2014 / \mathrm{FA} / 113$, J.J and L.Mc.L [2013] No.10 HLC, Latvian CA Ref No.25-1.3/13 and D v N and D (By her Guardian ad Litem, ) [2011] EWHC 471 (Fam). For further information please see the country reports.

${ }^{34}$ See Case C-403/09 Detiček [2009] ECR I-12193 and A Dutta and A Schulz, "First Cornerstones of the EU Rules on Cross-Border Child Cases: The Jurisprudence of the Court of Justice of the European Union on the Brussels IIa Regulation from C to Health Service Executive" (2014) Journal of Private International Law 1, 1417. See the UK Supreme Court's warning about reading across the CJEU's restrictive interpretation of Art 20 of Brussels IIa to Art 11 of the 1996 Convention In the matter of J (a child) [2015] UKSC 70, paras 27-28. It is noted that the CJEU has not dealt with a case where the State has issued measures under Art 20 to protect the child on return.

${ }^{35}$ Hague Convention of 1996 on the Protection of Children. The Convention is in force for all EU Member States. See http://www.hcch.net/index en.php?act=conventions.status\&cid=70, accessed 7 November 2015. ${ }^{36}$ Art 23(1), 1996 Convention.

${ }^{37}$ Art 11(2) and see the Practical Handbook on the Operation of the 1996 Child Protection Convention (HCCH, 2014), p 141, available at http://www.hcch.net/index_en.php?act=publications.details\&pid=6096\&dtid=3, accessed 23 November 2015.
} 
judges are encouraged to assume that the authorities in the State of the child's habitual residence will take the necessary measures to protect a child from physical or sexual abuse. ${ }^{38}$ In cases where that trust has broken down or not been properly established judges may not take the risk of returning children under the 1980 Convention. The 1996 Convention gives the judges in the State where the child is present the confidence that they can order any "necessary" protection measures which will be recognised in the State of the child's habitual residence (if it is also a party to the 1996 Convention) in the crucial period when the child is returning to that country (usually with the abducting parent) before the courts there have a chance to deal with the case. ${ }^{39}$

In a case where the child concerned has his or her habitual residence on the territory of an EU Member State the rules in the 1996 Convention can only apply within the European Union "in relation to matters not governed by this Regulation." (Article 62(1) of Brussels IIa). Does Article 11(1) of the 1996 Convention concern "a matter not governed by" the Brussels IIa Regulation? In the Purrucker case ${ }^{40}$ the Court of Justice expressed in an obiter dicta that Article 11(1) of the 1996 Convention creates a rule of jurisdiction and that therefore the measures taken under that provision qualify to be recognised and enforced in other Contracting States to that Convention. The Court contrasted this with Article 20 of the Brussels IIa Regulation which is not a rule of jurisdiction and does not authorise the creation of measures which qualify for recognition and enforcement under the Regulation. The Court did not decide whether Article 11(1) of the 1996 Convention can be used in intra-EU cases but it did refer positively to Advocate General Sharpston's Opinion in the case which took the view that recognition and enforcement of urgent provisional and protective measures given by a Member State not having jurisdiction under the Regulation for the substance of the matter is "not a matter governed" by the Regulation. ${ }^{41}$

\footnotetext{
${ }^{38}$ Although it is noted that judges applying only the Hague 1980 Convention are more likely to refuse to accept an argument based on Art 13(1)(b) than judges within the EU. Further judicial return rates generally appear to be lower within the EU than globally on the basis of the 2008 study. See N Lowe and V Stephens, supra n 12, $55-56$ and 61.

${ }^{39}$ On the legal correctness and advantages of using Art 11 of the 1996 Convention to secure a "'soft landing' for children whose return to their home country is ordered" see Hans van Loon, The Brussels IIa Regulation: towards a review? (European Parliament, 2015) para 3.1.3 and the unanimous endorsement of his view by the UK Supreme Court, In the matter of J (a child) [2015] UKSC 70, paras 31-33.

${ }^{40}$ Case C-256/09 Purrucker ECLI:EU:C:2010:437, see paras 87-90.

${ }^{41}$ Ibid at para 92 referring to para 176 of AG Sharpston's Opinion. Mostyn J used Art 11 of the 1996 Convention in two intra-EU child abduction cases without discussing the issue of whether the protective measures he was ordering under Art 11 were not a "matter governed" by the Brussels IIa Regulation, see $B v B$ [2014] EWHC 1804 (Fam) and $R B v D B$ [2015] EWHC 1817 (Fam) [10]-[11] and [29]. The UK Supreme Court did not address the issue of whether or not protective measures under Art 11 of the 1996 Convention are not a
} 
A revised Brussels IIa Regulation should at least ensure that all EU Member States can take in intra-EU cases the kind of urgent and necessary provisional measures for an abducted child envisaged by Article 11 of the 1996 Convention. The Regulation should clarify the links between Article 11(4) of Brussels IIa and Article 11 of the 1996 Convention, possibly in a Recital, and a new Practice Guide should emphasise the importance of utilising these provisions in Article 13(1)(b) cases. ${ }^{42}$ As an alternative to applying Article 11 of the 1996 Convention in intra-EU cases the Brussels IIa Recast could bring the existing Article 20 of the Regulation into the jurisdiction chapter and remove the reference to national law thereby mirroring Article 11 of the 1996 Convention. This route of amending Article 20 of Brussels IIa may be preferred if the EU legislature is willing to go further than the text of the 1996 Convention in the jurisdiction it grants to the courts where the child is present and/or in the recognition and enforcement provided within the EU to the protective measures granted by those courts. Whichever route is adopted the Regulation could, and should, go further than the scope of Article 11 of the 1996 Convention and also include a provision, which allows urgent protective measures for the returning abducting parent (usually the mother). This should include financial support to allow him or her to return and the provision of a safe place to live until the courts in the State of origin have given a decision on the child's custody and residence. As 'mutual trust' already exists in the EU it should be relatively simple to require that these orders are automatically enforceable in the State of the habitual residence of the child until a court there has an opportunity to decide the issues for itself. ${ }^{43}$

The study shows that Article 13(1)(b) Hague is used more often than the other Article 13 exceptions, and often used incorrectly in relation to the failure to take account of Article

\footnotetext{
"matter governed" by the Brussels IIa Regulation In the matter of $J$ (a child) [2015] UKSC 70 but without making any adverse comment did note that Mostyn $\mathrm{J}$ had used it in $B v B$ (see para 31).

${ }^{42}$ It is of course acknowledged that there will be some cases where it is necessary to refuse the return of the child on the basis of Art 13(1)(b) in order to protect the child, but judges are often failing to utilise these additional provisions that could help in certain cases.

${ }^{43}$ Regulation No 606/2013 of the European Parliament and of the Council of 12 June 2013 on mutual recognition of protection measures in civil matters, [2013] OJ L181/4, applies to protection measures issued on or after 11 January 2015 that do not fall within the scope of Brussels IIa (see Art 2(3) of the Protection Measures Regulation). This means that the Protection Measures Regulation could be used by courts in the State of refuge to issue orders for the protection of an abducting parent returning with the child to an EU Member State other than Denmark. However, it is not clear whether a "protection measure" under Regulation No 606/2013 would extend to financial support for the abducting parent including securing a safe place for the abducting parent to live in in the State of habitual residence of the child pending the outcome of a hearing in the courts of that State on the custody of the child. Such matters should be covered by a special provision in the Brussels IIa Recast. For an analysis of Regulation No 606/2013 and its relationship with Brussels IIa see A Dutta, "Cross-border protection measures in the European Union" (2016) Journal of Private International Law 169. For an early use of Regulation No 606/2013 in an intra-EU child abduction case without a careful analysis of the scope of that Regulation, see Mostyn J in $R B v D B$ [2015] EWHC 1817 (Fam) [30]-[31].
} 
11(4) Brussels IIa. The study also indicates a relatively low use of Article 13(2) Hague concerning the views of the child. The child's objections were used solely as the basis for the refusal of return in nine cases, so 14 per cent. In the 2008 study the child's objections accounted for 31 per cent of the global Article 13 non-returns, ${ }^{44}$ and in the 2005/06 study the finding is also 31 per cent, both much higher than the findings in the present study. ${ }^{45}$ This discrepancy seems unusual, in relation to the global study, because Brussels IIa requires that all children are heard unless inappropriate, ${ }^{46}$ whereas the 1980 Hague Convention does not contain a requirement to hear the child. ${ }^{47}$ However it is noted that Baroness Hale has held that the Regulation required a fresh look at hearing children's views. ${ }^{48}$ English judges now treat Hague international child abduction proceedings in the same way as EU proceedings and children 6 years and above are almost always heard. ${ }^{49}$

This approach is not EU wide, for example, the relevant Belgian law provides that only children of 12 years and older must be informed that they have a right to be heard. It is then up to the child to decide whether they want to be heard. Children under 12 are only heard if this is requested by the child, the public ministry or the parents. ${ }^{50}$ Judges are informed of the alternative requirement in Brussels IIa during mandatory training for new judges, but it is unlikely that children under 12 will be heard in international Hague proceedings. ${ }^{51}$ In the Netherlands in domestic family law cases only children over 12 are routinely heard. This approach may be followed in Article 11(7)-(8) Brussels IIa cases. Only in Hague return proceedings where jurisdiction is concentrated in The Hague are children of 6 and over routinely heard. ${ }^{52}$ It is also unusual that the percentage of Article 13(2) refusals in cases where Article 11(8) Brussels IIa was used is lower than the earlier finding in relation to EU refusals. However Lowe indicates that there are more judicial refusals based on Article 13(2) where the abducting parent is the father (31\%) compared to 13 per cent where the abducting parent is the mother. ${ }^{53}$ If this is generally the case, then this could support the hypothesis that mothers are more likely to choose not to initiate Article 11(6)-(8) proceedings, potentially because they

\footnotetext{
${ }^{44} \mathrm{~N}$ Lowe and V Stephens, supra n 12, 61.

${ }^{45} \mathrm{~K}$ Trimmings, supra $\mathrm{n} 17,90$.

${ }^{46}$ Art 11(2).

${ }^{47} \operatorname{Art} 13(2)$.

${ }^{48}$ Re D (A Minor) (Abduction: Rights of Custody) [2006] UKHL 51.

${ }^{49} \operatorname{Re} M$ (Republic of Ireland)(Child's Objections)(Joinder of Children as Parties to Appeal) [2015] EWCA Civ

26. For further information see the England and Wales report.

${ }^{50}$ Information provided at an interview on 15 May 2015. For further information please see the Belgian report, available at the project website.

${ }^{51}$ For more information on hearing the child in the context of Art 11(8) proceedings see below at section D.1.

${ }^{52}$ Information provided by a Dutch judge during an interview on 2 November 2015.

${ }^{53} \mathrm{~N}$ Lowe and V Stephens, supra n 12, 63.
} 
cannot afford to, although this suggestion would need further exploration. An alternative explanation might be that parents are more likely to respect a Hague non-return order when it is based on their child's views and are therefore less likely to initiate further proceedings in the State of origin.

Given the structure of the Brussels IIa Regulation a logical assumption would be that Article 13(1)(b) Hague refusals should be lower across the EU than globally and Article 13(2) Hague refusals should be higher, however the opposite appears to be the case across this sample. This could suggest a reluctance to apply Article 11(4) Brussels IIa and a lack of trust that protective measures will be enforced. If so this could put into question the principle of mutual trust if judges are more likely to return children globally than within the EU. ${ }^{54}$ An alternative analysis could be that until recently certain EU countries had less experience applying the Convention than other countries globally so it is taking time to build experience and this pattern could change in the future. For example Latvia, a country renowned for issuing Hague non-return orders, ${ }^{55}$ moved to concentrated jurisdiction in Hague cases in March 2015. Now only around 12 judges will be responsible for hearing child abduction cases and hopefully this will allow the judges to build expertise in this area. ${ }^{56}$ The present study shows a high reliance on Article 13(1)(b) Hague and an underuse of Article 11(4) Brussels IIa. If Article 11(6)-(8) Brussels IIa proceedings are retained it would be useful to limit these to Hague refusals where at least one of the grounds for refusal was Article 13(1)(b) Hague. Article 13(1)(b) Hague has been by far the most significant trigger for Article 11(6)-(8) Brussels IIa proceedings (involved in 40 of the 63 cases found in our study).

Given the very limited effectiveness of Article 11(6)-(8) Brussels IIa and the time and costs involved for the parties and the judges it should be scrapped. EU Member States should be able to have the mutual trust in each other's courts that if a Hague return has been refused

\footnotetext{
${ }^{54}$ Weller suggests that 'the justificatory force of mutual trust is limited and that using mutual trust as a legal fiction does not work'. (M Weller, "Mutual Trust: In search of the future of European Union private international law" (2015) Journal of Private International Law 64, 85). This suggests that mutual trust is something that still needs to be developed rather than something that is just presumed as a method for guaranteeing the mutual recognition, provided for in Art 81 Treaty on the Functioning of the European Union. ${ }_{55}$ Apart from in 2008, where 8 cases went to the Court of Appeal and returns were ordered. Unfortunately one of these cases was $X v$ Latvia where the Latvian authorities were later criticised for ordering the return by the ECtHR ( $X v$ Latvia (Application no. 27853/09) 26 November 2013 and see P Beaumont, K Trimmings, L Walker and J Holliday "Child Abduction: recent jurisprudence of the European Court of Human Rights" (2015) International and Comparative Law Quarterly 1 and P McEleavy, "The European Court of Human Rights and the Hague Child Abduction Convention: Prioritising Return or Reflection?” (2015) Netherlands International Law Review 365).

${ }^{56}$ Information gained at an interview on 15 June 2015, further information can be found in the Latvia report, available at the project website.
} 
in an intra-EU case then the Hague Convention has been applied correctly, the habitual residence of the child has shifted to the State of refuge and the courts there are in the best place to determine issues of parental responsibility and access. If a case for retention can be made it is best in relation to Article 13(1)(b) Hague refusals because this is the only ground that generates more than a completely de minimus number of Article 11(6)-(8) proceedings. Also because more of the evidence in these cases may exist in the habitual residence of the child before the abduction because the suitability of the left-behind parent to exercise parental responsibility and perhaps even unsupervised access has been called into question by the finding of the State of refuge that there is a grave risk of harm or an intolerable situation if the child is returned to the State of habitual residence prior to the abduction. It is not obvious what the compelling case is for allowing Brussels IIa proceedings to take place where the courts of the State of refuge have found that the left-behind parent has actually consented to or otherwise acquiesced in the removal/retention. ${ }^{57}$ Where the reason for non-return is the child's objections it is particularly difficult to justify allowing the courts of the habitual residence of the child before the abduction to give a decision on residence which requires the child to live in that State with the non-abducting parent, given the strong evidence in our study that these orders are being made without hearing the child and the greater practical difficulty for the courts of the habitual residence to hear the child in abduction cases compared to the courts of the State of refuge. ${ }^{58}$

\section{Article 11(6)-(8) proceedings}

\section{(a) Decision and process}

Out of the 66 cases the judge in the State of habitual residence of the child (State of origin) reached a decision requiring the return of the child and issued an Article 42 certificate in 28 cases. So in just over 42 per cent of cases a return order was made, in 42 per cent of cases the return order was denied and in 15 percent of cases the outcome is unknown. ${ }^{59}$

\begin{tabular}{|l|c|c|c|c|}
\hline & \multicolumn{3}{|c|}{ Decision of court of origin } & \\
\cline { 2 - 4 } Member State & $\begin{array}{c}\text { Child to be } \\
\text { returned }\end{array}$ & $\begin{array}{c}\text { Child should } \\
\text { not return }\end{array}$ & unknown & Total \\
\hline
\end{tabular}

\footnotetext{
${ }^{57}$ See below at section E. 4 for further details.

${ }^{58}$ See eg Case C-491/10 PPU Aguirre Zarraga v Pelz [2010] ECR I-14247.

${ }^{59} \mathrm{In}$ some cases this is because the outcome was still pending when the information was provided or in other cases there had been an initial hearing and then the judge had referred a question to the judge in the State of refuge and no further proceedings could be found.
} 


\begin{tabular}{|l|r|r|r|r|}
\hline Austria & 0 & 0 & 1 & 1 \\
Belgium & 4 & 3 & 0 & 7 \\
Czech Republic & 1 & 0 & 0 & 1 \\
France & 1 & 2 & 1 & 2 \\
Germany & 2 & 3 & 1 & 6 \\
Greece & 1 & 0 & 0 & 1 \\
Hungary & 0 & 3 & 0 & 1 \\
Ireland & 6 & 1 & 2 & 5 \\
Italy & 0 & 0 & 2 & 17 \\
Latvia & 1 & 9 & 1 \\
Luxembourg & 2 & 1 & 0 & 1 \\
Portugal & 0 & 0 & 0 & 3 \\
Romania & 1 & 0 & 1 & 5 \\
Slovenia & 2 & 4 & 1 & 1 \\
Spain & 4 & 0 & 0 & 3 \\
UK-England \& Wales & 28 & 1 & 0 & 11 \\
Total & 5 & 2 & 66 \\
\hline
\end{tabular}

Figure 4: Article 11(8) decision

In some cases the judges issued a final order requiring the return of the child, ${ }^{60}$ and in other cases the judges issued a provisional decision in order for them to hold a full custody, or welfare, hearing following the child's return. ${ }^{61}$ The main reason for doing this was because the judges had been unable to hear the parties, so they ordered the return so that all parties could be heard sufficiently. ${ }^{62}$ In some cases the parties had been given numerous opportunities to be heard, ${ }^{63}$ however in other cases no attempt had been made to hear the parties and in one specific case the certificate was issued so that the parties 'will' be given an opportunity to be heard, on their return. ${ }^{64}$ In such cases the validity of the certificate has to be questioned because the point in the certificate is to certify that the parties 'were' given an opportunity to be heard. ${ }^{65}$ In other cases Article 11(6)-(8) Brussels IIa proceedings have been treated purely as a re-evaluation of

\footnotetext{
${ }^{60}$ See for example, Re A [2006] EWHC 3397 (Fam), and Aguirre Zarraga, supra n 58. This number includes $O . K v K$ [2011] IEHC 360 where the judge temporarily ordered the return of the child and issued an Article 42 certificate so that the child could finish the school year in Ireland, with the child to return to Poland after that and live there (although the final order was essentially a non-return an Art 42 certificate was still issued).

${ }^{61}$ For example, $D v N$ and $D$ (By her Guardian ad Litem, ) [2011] EWHC 471 (Fam).

${ }^{62}$ For more detailed information on hearing the parties, see below at sections D and E.

${ }^{63}$ D $v$ N and D (By her Guardian ad Litem, ) [2011] EWHC 471 (Fam), where the abducting parent's failure to cooperate also meant that the Guardian could not observe the child in the State of refuge prior to the judge making the order.

${ }^{64}$ TQ13P00079/ZC14P00064 EWHC (Fam) 4 July 2014 (Unreported).

${ }^{65}$ For further analysis of Art 42 certificates, see below at s E, and see P McEleavy, "The New Child Abduction Regime in the European Union: Symbiotic Relationship or Forced Partnership" (2005) Journal of Private International Law 5, 33.
} 
the Article 13 Hague decision, ${ }^{66}$ and not a broader welfare test, and in other cases judges have ordered a return with the main aim being to re-establish contact with the left-behind parent ${ }^{67}$

Article 11(6)-(8) Brussels IIa proceedings should not be used simply to review the Article 13 Hague decision on non-return. This does not promote mutual trust. Article 11(7) states that the parties are invited to make submissions to the court so that the "court can examine the question of custody of the child'. There is nothing in Article 11(6)-(8) Brussels IIa that suggests the court should review the Article 13 Hague decision. In order to issue a certificate under Article 42 Brussels IIa the court is supposed to take account of the reasons for and evidence underlying the Hague non-return order, ${ }^{68}$ but this is a procedural safeguard for protecting the child, due to the abolition of exequatur, rather than reviewing the decision on non-return (which is the job of an appellate court). Any decision taken by the court of the habitual residence of the child under Article 11(6)-(8) should be a full welfare assessment that takes account of the best interests of the child. It is recognised that in Povse the CJEU held that the court can order the return of the child for the purpose of custody proceedings, ${ }^{69}$ but this does not allow courts to order the return of the child just because they will not be at a grave risk of harm. ${ }^{70}$ Any decision under Article 11(6)-(8) should only be made after a best interest of the child assessment is carried out. These proceedings are not the same as summary return proceedings that should be taken urgently and where evidence should be kept to a minimum. Instead a much broader assessment should be made, evidence should be collected and the parties should be heard. ${ }^{71}$ It is clear that the proceedings are different to the earlier summary proceedings as no timeframe is set, ${ }^{72}$ and judges are supposed to meet the requirements in Article 42, which also indicate a fuller examination. Interviews with Cafcass officers, ${ }^{73}$ practitioners and judges have indicated that it is possible to carry out a full welfare examination

\footnotetext{
${ }^{66}$ See for example, Juvenile Court Florence, May 2014, CA No 149/12 and Juvenile Court Sassari, 5 August 2013, CA No $1 / 10$.

${ }^{67}$ See for example M.H.A v A.P [2013] IEHC 611, Minister for Justice and Equality acting as Central Authority $v$ M.F [2015] IEHC 538. In Mv T (Abduction: Brussels II Revised, Art 11(7)) [2010] EWHC 1479 (Fam) an English judge made an order to re-establish contact but did not issue an Art 42 certificate.

${ }^{68} \operatorname{Art~42(2)(c).~}$

${ }^{69}$ Case C-211/10 PPU Povse v Alpago [2010] ECR I-00673.

${ }^{70}$ See the decision of Juvenile Court Florence, May 2014, CA No 149/12.

${ }^{71}$ At least they should be given an opportunity to be heard.

${ }^{72}$ Art 11(3) introduces a six week deadline in respect of Hague Convention cases. No deadline was introduced in relation to Art 11(6)-(8) judicial proceedings (only for notifying the court of the non-return order and initiating an application under Art 11(7)) suggesting that the nature of the order is different. If both proceedings were designed to be summary, although Art 11(7) suggests to the contrary, then it would have been possible to include timelines for both sets of proceedings.

${ }^{73}$ Child and family court advisory and support service, England and Wales. Cafcass officers are professionals (mostly social workers) who speak to children to try and determine their wishes and feelings in order to provide a report for the court on the child's welfare.
} 
when the child is in another Member State and collect the evidence required to make an adequate assessment. ${ }^{74}$ Unfortunately this does not appear to be happening regularly, the proceedings are not being treated in the same way across the EU, and Article 42 certificates are being issued where there are distinct differences in analysis by courts. ${ }^{75}$ The cases where the judge in the State of origin reached a decision requiring return and an Article 42 certificate was issued can be broken down to distinguish between final and interim orders; and to distinguish between cases where there was a full welfare analysis and where there was not. The results indicate that a number of the decisions in which an Article 42 certificate was issued were intended to be final orders, but only a small number of these cases could be considered to be decided as a result of a full welfare analysis.

\begin{tabular}{|c|r|l|}
\hline Type of 11(8) order & Number & \multicolumn{1}{|l|}{ Percent } \\
\hline Final & 13 & 46.4 \\
Interim & 5 & 17.9 \\
Unknown & 10 & 35.7 \\
Total & 28 & 100 \\
\hline
\end{tabular}

Figure 5: Art 11(8) orders by type

\begin{tabular}{|l|r|r|}
\hline Were the welfare requirements met? & Number & Percent \\
\hline $\begin{array}{l}\text { Yes - Full Welfare } \\
\text { Requirements Met }\end{array}$ & 5 & 17.9 \\
No - Full Welfare & 12 & 42.9 \\
Requirements Not Met & 11 & 39.3 \\
Insufficient Information & 28 & 100 \\
Total & & \\
\hline
\end{tabular}

Figure 6: Did the court's decision appear to be a full welfare analysis ${ }^{76}$

\footnotetext{
${ }^{74}$ For further information see s D.1 below.

${ }^{75}$ Compare the decision in Bradbrooke supra $\mathrm{n} 33$, where the Belgian Court of Appeal made a detailed analysis of the child's interests including his needs and the benefits of maintaining a relationship with both his parents for his full development, with an Italian decision where the judge considered that even if the children opposed the return they should be returned anyway if they were not at risk of harm (n 70). In both cases an Art 42 certificate was issued.

${ }^{76}$ This refers to cases which meet all the requirements in Art 42 and cases where the judge made the best of a bad situation. Cases that do not meet the requirements in Art 42 and cases which just review the Art 13 provisions do not meet the standards of a full welfare analysis. For further information see section D below and the country reports.
} 
There were only five cases in which orders were made, that were intended to be final orders, where it is clear that a full welfare analysis was carried out. In seven of the cases where the Article 11(8) order was intended to be a final order a full welfare analysis was not carried out, and in the remaining case the answer is unclear.

Due to the divergent treatment of Article 11(6)-(8) Brussels IIa proceedings a revised Regulation needs to clarify what the process is, emphasising the focus on welfare (as the text currently suggests) in order to promote mutual trust. Povse should be reversed on one point so that Article 42 certificates can only be issued where there is a final residence or custody order based on a full welfare assessment which requires that the child should spend the majority of their time living in the State of origin. ${ }^{77}$ If their primary residence is to be in the State of refuge, usually with the abductor, then the child should be allowed to remain where he or she is and should become habitually resident there. It is recognised that there is now a preference for awarding joint custody and residence, as the child has the right to know both their parents, ${ }^{78}$ however any order should reflect the reality of the situation ${ }^{79}$ and must be practical. Children have to have a main residence, particularly once they start school, as it is impractical for them to spend half the year in one school system and the other half of the year in another incompatible school system. It is also apparent that in many of these cases the parties do not have a lot of money. In many cases the parties cannot afford to be making weekly trips across Europe, and in the case of younger children the child cannot travel alone, so one of the parents will need to take time off work to make the trip. ${ }^{80}$ This is perhaps not such a big problem in socalled 'big money' cases because the parents might be able to reach some sort of agreement where the child spends the majority of their time at boarding school and splits the remainder of their time equally with both parents, some agreement is made in relation to maintenance or

\footnotetext{
${ }^{77}$.The judge must be satisfied that it is in the best interests of the child to live with an appropriate custodian there.

${ }^{78}$ This is the preferred approach in several States, for example, Belgium where the Belgian legislation has provided for alternate residence since 2006 see Kruger, supra $\mathrm{n}$ 13, and this general preference was referred to by the judge at the interview in May 2015, New Zealand (George, ibid, 188 and 191) and in England where s 12 of the Children and Families Act 2014, which rebrands residence and contact orders under s 8(1) of the Children's Act as 'child arrangement's orders' to prevent the feeling of winners and losers (although it is unlikely to change court practice which already aims for the child to have contact with both parents).

${ }^{79}$ See for example, Re A, HA v MB (Brussels II Revised: Article (11)7 Application) [2007] EWHC 2016 (Fam), paras 111-121.

${ }^{80}$ Judges should not make orders that require contact which the parties cannot afford. This will only increase debt and adversely impact on the welfare of the child if the parents then cannot afford to look after the child (see for example Mv T (Abduction: Brussels II Revised, Art 11(7)) [2010] EWHC 1479 (Fam) paras 48-52 and 9094, where it was decided that contact should take place twice a year for 7-10 days at a time). As Herring and Taylor explain one reason that parents relocate in the first place is to escape financial instability and be closer to family support networks in order to protect the future well-being of themselves and their child. J Herring and $\mathrm{R}$ Taylor, supra n 76, 523.
} 
one parent is happy to and can easily afford to make the trip to see the child regularly. In any case judges need to reach a practical decision that is in the best interests of the child, and works for the parties, which will most likely involve the child spending the majority of their time with one parent in one Member State.

\section{(b) Implementation}

A return was ordered in 28 Article 11(6)-(8) Brussels IIa cases, however the order was only definitely implemented in 7 cases. In the remainder of these cases, the child was not returned to the State of origin in 14 cases and the outcome is unknown in 7 cases.

\begin{tabular}{|c|c|c|c|c|c|c|}
\hline & \multirow[b]{2}{*}{ Member State } & \multicolumn{4}{|c|}{ Has the child been returned? } & \multirow[b]{2}{*}{ Total } \\
\hline & & Yes & No & Unknown & Re-abducted & \\
\hline & Belgium & 0 & 2 & $\overline{1}$ & 1 & 4 \\
\hline & Czech Republic & 1 & 0 & 0 & 0 & 1 \\
\hline & France & 0 & 1 & 0 & 0 & 1 \\
\hline & Germany & 0 & 1 & 0 & 1 & 2 \\
\hline & Greece & 0 & 0 & 1 & 0 & 1 \\
\hline & Italy & 1 & 4 & 1 & 0 & 6 \\
\hline & Ireland & 1 & 0 & 2 & 0 & 3 \\
\hline & Luxembourg & 1 & 0 & 0 & 0 & 1 \\
\hline & Portugal & 0 & 1 & 1 & 0 & 2 \\
\hline & Slovenia & 0 & 1 & 0 & 0 & 1 \\
\hline & Spain & 0 & 2 & 0 & 0 & 2 \\
\hline & UK-England \& Wales & 1 & 2 & 1 & 0 & 4 \\
\hline Total & & 5 & 14 & 7 & 2 & 28 \\
\hline
\end{tabular}

Figure 7: Outcome of the return order issued by the court in the State of origin

Consequently out of the 28 orders, which are automatically enforceable because they were accompanied by an Article 42 certificate, only 25 per cent of these orders were implemented and only 18 per cent were enforced legally. In relation to the five orders that were enforced legally the enforcing States (States of refuge) were Malta, ${ }^{81}$ Poland, Portugal (on two occasions) and Slovenia. In the five cases where the order was legally enforced, three of these orders were final orders, in the other two cases the type of order was unknown. In two out of the five cases a full welfare analysis was carried out; ${ }^{82}$ in the other three cases the depth of the

\footnotetext{
${ }^{81}$ In this case Re A (Custody Decision after Maltese non-return Order) [2006] EWHC 3397 (Fam), the child was finally returned to England after much effort, for him to return to Malta six months later, information provided at an interview on 20 May 2015.

${ }^{82}$ These cases are $O K v K$, supra n 60, where the child was only returned from Poland for a temporary period, in order to have one year of schooling in Ireland while living with the mother, before relocating permanently to Poland to live with the father and Re A, ibid, where the child went back to Malta.
} 
analysis by the court is unknown. In relation to the two re-abductions one order was final and the other order was interim.

The findings show that Article 11(6)-(8) Brussels IIa proceedings are largely ineffective as the orders are rarely enforced legally, despite the fact that they are automatically enforceable. These findings coincide with the outcome in the two well-known cases in this area: Aguirre Zarraga ${ }^{83}$ and Povse. ${ }^{84}$ Despite the ongoing litigation in these cases and clear rulings from the Court of Justice of the European Union (CJEU) in both cases and the European Court of Human Rights in the latter case that the orders should be enforced and the children returned, the children were never returned to the State of origin. Following the CJEU decision in Bradbrooke, the Brussels Court of Appeal made an order requiring that the child return to Belgium and live with his father on 20 February $2015 .^{85}$ The child returned to Belgium on 28 February 2015, a week after the order. The mother permitted the father to see the child at a hotel in Poland, for what she thought was access, and the father took the child back to Belgium. At this time the mother was unaware of the Belgian order as the papers had not yet been delivered, so effectively this was a re-abduction. The child now lives with his father in Belgium, and speaks with his mother, irregularly, over skype. The child is looked after by a Polish Nanny to help with the language barrier. A hearing was set for June 2015 but the mother did not appear. The next judicial intervention was planned for March 2016, by which point the child's relationship with the father should have improved as were the intentions behind the return order, but it is likely that the relationship with his mother will have broken down. Earlier decisions indicate that the mother would have been permitted to relocate if she had sought permission from the Belgian authorities before she took the child to Poland. ${ }^{86}$ The other case

\footnotetext{
${ }^{83}$ Aguirre Zarraga supra n 58.

${ }^{84}$ Case C-211/10 PPU Povse v Alpago [2010] ECR I-00673 and Povse v Austria (App no 3890/11) 18 June 2013. It is noted that following the decision of the ECtHR in Povse v Austria the father also made an application against Austria and on this occasion the ECtHR held that there had been a violation of Article 8 ECHR by the Austrian authorities (M.A v Austria (App no 4097/13 15 January 2015).

${ }^{85}$ Bradbrooke c Aleksandrowicz, R.G. N: 2014/JR/73 et $\mathrm{N}^{\circ}: 2014 / \mathrm{FA} / 113$.

${ }^{86}$ In Bradbrooke there had been ongoing proceedings in Belgium for contact but the question of relocation does not seem to have been raised. It is known that in some cases parents carefully plan an abduction which they know is contrary to the law. However there are a variety of reasons why a parent may not seek a relocation order before relocation. They might not realise they are supposed to do this, certain national laws might not be favourable to relocation, the parent might be fleeing domestic violence and leaving when they have a chance, or they might not be able to pay for the procedure. In TQ13P00079/ZC14P00064 EWHC (Fam) 4 July 2014 (Unreported), the mother had intended to seek a relocation order (which would most likely have been granted). She then discovered that she would not receive legal aid for her application, she could not afford a lawyer, so she left without the courts' permission. Given the legal aid cuts and the limits on access to justice the actions of these parents are sometimes understandable. This perceived saving in government funding, due to legal aid cuts within the UK, can result in ongoing proceedings and increased animosity between the parties, which may result in more spending in the long run and increased instability for the parties.
} 
where the father re-abducted the child was Rinau,${ }^{87}$ a case also dealt with by the CJEU. Given the problems surrounding the Article 11(6)-(8) procedure, and the fact that the ongoing court proceedings are likely to increase conflict and antagonism between the parties and lengthen the period of instability, neither of which are in the interests of the child, ${ }^{88}$ the lack of enforcement of these orders questions the viability and suitability of the process. ${ }^{89}$

\section{Hearing the parties and the Article 42 certificate}

An important element of any Article 11(8) decision is the Article 42 certificate. If the court fails to issue a certificate with the decision, or the certificate is incomplete then the decision is not automatically enforceable. ${ }^{90}$ As previously mentioned, the certificate was introduced in order to create safeguards for the protection of the rights of the parties in relation to the abolition of exequatur. However it is questionable whether the certificate and its 'requirements', 91 are capable of protecting the parties' rights in their current form. Before issuing a certificate judges should ensure that the child, where appropriate, and the parties are given an opportunity to be heard, ${ }^{92}$ that they have taken account of the reasons for and evidence

\footnotetext{
${ }^{87}$ Case C-195/08 PPU, Rinau ECLI:EU:C:2008:406.

${ }^{88}$ See for example, T Kruger, supra n 13, 200-205 and R DeBoard-Lucas et al, "Interparental Conflict in Context: Exploring Relations Between Parenting Processes and Children's Conflict Appraisals" (2010) Journal of Clinical and Child Adolescent Psychology 163, G Harold et al, Not in Front of the Children?: how conflict between parents affects Children (One Plus One Marriage \& Partnership Research, 2001) and J Reynolds et al, Parental Conflict: Outcomes and Interventions for Children and Families (The Policy Press, 2014). In particular, studies have found that children who perceive themselves to be partially responsible for the conflict between their parents are more likely to feel ashamed and sad (DeBoard Lucas et al 173), see also J Grych and F Fincham, "Children's Appraisals of Marital Conflict: Initial investigations of the cognitive-contextual framework" (1993) Child Development 215.

${ }^{89}$ A Spanish solicitor's response, to the solicitor's questionnaire, indicates that she does not find Art 11(6)-(8) proceedings useful in practice and finds them time consuming. Her experience is with cases where after the Hague non-return the new residence in Spain is accepted and custody proceedings take place there. In her experience all the parties are heard in court in such cases, or the parties reach an agreement which is later ratified by the court, or the left behind parent decides not to pursue contact at all. During an interview with a Belgian judge (May 2015) it was stated that the procedure is good in theory, but does not work in practice. In other interviews the interviewee was at first positive about the procedure but then went on to state negative points. The only positive seemed to be in cases where there were concerns that the court in the State of refuge had reached the wrong decision. The wrong approach to 1980 return proceedings might be better rectified by concentration of jurisdiction and further training for judges, rather than the additional procedure in Art 11(6)-(8) Brussels IIa.

${ }^{90}$ Arts 11(8), 40(1)(b) and 42.

91 Art 42(2).

${ }^{92} \operatorname{Art} 42(2)(b)$.
} 
underlying the Hague non-return order, ${ }^{93}$ and they have included details of any protective measures taken. ${ }^{94}$

\section{Hearing the child}

Under international law, a child has a right to be given the opportunity to be heard in situations that affect them. ${ }^{95}$ The requirement to give the child the opportunity to be heard during the course of civil legal proceedings is found within Article 12(2) of the United Nations Convention on the Rights of the Child. This right is upheld within the European Union where the right for the child to be given an opportunity to be heard is found within Article 24(1) of the Charter of Fundamental Rights of the European Union and is also regarded as integral to providing the child with a fair trial under Article 6 of the European Convention on Human Rights. ${ }^{96}$

In 2005 the Brussels IIa Regulation raised the standards for intra-EU 1980 Hague Convention proceedings. Under the Convention there is no explicit requirement to hear the child. During proceedings involving Articles 12 and 13 of the Hague Convention in an intraEU case ' $(\ldots)$ it shall be ensured that the child is given the opportunity to be heard during the proceedings unless this appears inappropriate having regard to his or her age or degree of maturity. ${ }^{97}$ Brussels IIa went further still to protect the right of the child to be heard in that the enforcement of the return order under Articles 11(8) and 42 is conditional on the child having been given the opportunity to be heard during the proceedings, unless this is inappropriate. ${ }^{98}$ This was seen as a necessary requirement in light of the abolition of the exequatur. ${ }^{99}$

\footnotetext{
${ }^{93} \operatorname{Art} 42(2)(c)$.

94 Art 42(2).

${ }^{95}$ United Nations Convention on the Rights of the Child (UNCRC) 1989 Art 12. Charter of Fundamental Rights of the European Union Art 24(1).

${ }^{96}$ UNCRC Art 12(2). General Comment No. 12 (2009): The Right of the Child to be Heard CRC/C/GC/12 (General Comment No. 12). European Convention on Human Rights Art 6. Charter of Fundamental Rights of the European Union Art 24 (1).

${ }^{97}$ Art 11(2) Brussels IIa Regulation. Under the 1980 Hague Convention there is no explicit requirement to give the child an opportunity to be heard during return proceedings. There is the possibility for the child to object to being returned under Art 13(2) of the 1980 Convention and the court can issue a non-return order on that basis if it feels that the objection is valid with regard to the age and maturity of the child; implying that the child has been given the opportunity to be heard in order to be able to express their objection.

${ }^{98}$ Art 42(2)(a) Brussels IIa Regulation. As the standard is set autonomously in the Regulation without any reference to national law it is for the CJEU to give guidance on what is "inappropriate" when the matter is referred to that Court by a national court. A broad approach should be taken to ensure conformity with Art 12 UNCRC whereby each child's maturity is assessed when the child is heard rather than having an arbitrary age requirement as happens under some national laws in the EU.

${ }^{99}$ In relation to other parental responsibility orders Art 23(2)(b) of the 1996 Hague Convention on Jurisdiction, Applicable Law, Recognition and Cooperation in Respect of Parental Responsibility and Measures for the Protection of the Child protects this fundamental right in that recognition of a measure issued by a court may be
} 
The text within Brussels IIa clearly supports the aims of the UNCRC and in theory should be commended for taking this approach. However, the findings of the present study indicate that in most intra-EU cases involving Article 11(6)-(8) Brussels IIa proceedings the child is not heard. Therefore, urgent reform is required in order to prevent such clear violations of the rights of the child.

The child's right to be heard is dependent on several subjective elements, such as whether the child in the eyes of the court is capable of forming their own views, with weight given in accordance to their age and maturity. ${ }^{100}$ The manner in which children are heard is in accordance with the national procedural rules, relating to the case, ${ }^{101}$ and these procedural rules can vary dramatically between Member States. In addition there are variations regarding the training and background of the person hearing the child, ${ }^{102}$ and the environment in which the child is heard, ${ }^{103}$ as well as the availability of appropriate technology to hear the child under the Taking of Evidence Regulation. ${ }^{104}$ It therefore has to be acknowledged that there is an inherent level of inequality and uncertainty connected to this right.

\section{(a) General practice under Article 11(6)-(8)}

Only 14 children out of the 70 were definitely heard, 38 were definitely not heard. There are four cases where the child was given the opportunity to be heard, ${ }^{105}$ and in 14 cases this

refused if the child has not been provided the opportunity to be heard and this approach is followed in intra-EU cases in Art 23(b) of Brussels IIa. K Boele-Woelki, F Ferrand, C Gonzalez-Beilfuss, M Jänterä-Jareborg, N Lowe, D Martiny, W Pintens, Principles of European Family Law Regarding Parental Responsibilities (Intersentia, 2007) 242.

${ }^{100}$ UNCRC Art 12(1). Charter of Fundamental Rights of the European Union Art 24(1). For a brief analysis of the issues surrounding age and maturity in relation to child abduction under the Hague Convention see $\mathrm{P}$ Beaumont and P McEleavy The Hague Convention on International Child Abduction (OUP, 1999) 191. ${ }^{101}$ UNCRC Art 12(1)(2).

${ }^{102}$ In some jurisdictions children are heard by trained social workers and psychologists, and in others they are heard by judges who may have no suitable training and limited experience with children (see the country reports for more details).

${ }^{103}$ Children can be heard in court (primarily older children), in a judge's chamber, in rooms specifically designated for this purpose which purport to be child friendly and in various settings representing the child's everyday life (see the country reports for more details). The importance of hearing the child in an appropriate environment in order to get the most reliable evidence should not be underestimated. The Committee on the Rights of the Child has indicated that children 'cannot be heard effectively where the environment is intimidating, hostile, insensitive or inappropriate for her or his age.' (General Comment No. 12, para 34).

${ }^{104}$ Council Regulation No 1206/2001 of 28 May 2001 on cooperation between the courts of the Member States in the taking of evidence in civil or commercial matters [2001] OJ L174/1.

${ }^{105}$ In three of these cases the children were given proper opportunities to be heard, but in two of these cases that was not possible due to the behaviour of the abducting parent ( $D v N$ and D (By her Guardian ad Litem,) [2011] EWHC 471 (Fam) and Re A [2006] EWHC 3397). In one case provisions were in place for the authorities in Ireland and Sweden to hear the child, but it is not clear from the case report whether the child was heard ( $E E$ and Judge O'Donnell v JS [2013] IEHC 418). The final case was Aguirre Zarraga supra $\mathrm{n}$ 58, where the child was given an 'opportunity' to be heard in court in Spain. The request for the child to be heard via a different mechanism was refused. 
information was unavailable. The submission of an Article 42 certificate does not guarantee that the child has been heard, however, according to the information provided only 20 per cent of the children were heard indirectly and none directly. It also seems that whether a court chooses to hear the child or not can be influenced by their desire merely to comply with the Article 42 certificate. In one case, the court openly stated that they had requested the children to be heard in the State of refuge simply to satisfy the requirements of the Article 42 certificate so that the children could be ordered to return. ${ }^{106}$ In another, the court decided that the child was too young to be heard, however stated that the child would be heard on his return to Ireland. The real reason that the child was not heard in the State of refuge was that the court in the State of origin did not have the means to interview the child in Poland and that it intended to do a full welfare hearing on his return. ${ }^{107}$

\begin{tabular}{|c|c|c|c|c|c|c|}
\hline & \multirow[b]{2}{*}{ Member State } & \multicolumn{4}{|c|}{ Was the child heard? } & \multirow[t]{2}{*}{ Total } \\
\hline & & Indirectly & No & Unknown & $\begin{array}{c}\text { 'Opportunity' } \\
\text { given }\end{array}$ & \\
\hline & Austria & 0 & 0 & 1 & 0 & 1 \\
\hline & Belgium & 1 & 7 & 0 & 0 & 8 \\
\hline & Czech Republic & 0 & 1 & 0 & 0 & 1 \\
\hline & France & 0 & 2 & 0 & 0 & 2 \\
\hline & Germany & 1 & 1 & 4 & 0 & 6 \\
\hline & Greece & 0 & 1 & 0 & 0 & 1 \\
\hline & Hungary & 0 & 1 & 0 & 0 & 1 \\
\hline & Ireland & 3 & 1 & 1 & 1 & 6 \\
\hline & Italy & 0 & 14 & 5 & 0 & 19 \\
\hline & Latvia & 1 & 0 & 0 & 0 & 1 \\
\hline & Luxembourg & 0 & 1 & 0 & 0 & 1 \\
\hline & Portugal & 1 & 2 & 0 & 0 & 3 \\
\hline & Romania & 2 & 2 & 1 & 0 & 5 \\
\hline & Slovenia & 0 & 1 & 0 & 0 & 1 \\
\hline & Spain & 0 & 1 & 1 & 1 & 3 \\
\hline & UK-England \& Wales & 5 & 3 & 1 & 2 & 11 \\
\hline Total & & 14 & 38 & 14 & 4 & 70 \\
\hline
\end{tabular}

Figure 8: Hearing the child

There are fourteen cases where the child was heard 'indirectly'. In some of these cases the child was heard under the Taking of Evidence Regulation, in other cases the child was heard through child welfare officers, ${ }^{108}$ as in national proceedings, either through officers from the State of

\footnotetext{
${ }^{106}$ Minister for Justice and Equality acting as Central Authority v M.F and anor [2015] IEHC 538 [14]. ${ }^{107}$ M.H.A v A.P [2013] IEHC 611 [40].

108 This term has been employed as a neutral term to describe various services in Member States such as: Cafcass, Legal Guardians, German Youth Welfare Office and the Latvian Orphans' 'court'. Please see the country reports for further details.
} 
origin travelling to the State of refuge or from reports written by officers in the State of refuge. In some cases the box was ticked but the child was not actually heard. It is unclear whether an initial application was made under the Taking of Evidence Regulation in all cases. Unfortunately, the present findings also highlight a problem with the courts accessing the equipment required that would support the Taking of Evidence Regulation. Access to videoconferencing facilities was difficult in many cases and often hindered by long waiting lists or complicated bureaucracy to obtain access to it. ${ }^{109}$

Interestingly there appears to be a link between the child being heard and the decision, by the court in the State of origin, not to issue a judgment accompanied by a certificate and allow the child to remain in the State of refuge. In the eleven cases where the court heard the child via some mechanism there was only one case where the court issued an Article 42 certificate requiring the final return of the child to live permanently in the State of origin, ${ }^{110}$ which raises the question as to whether this procedure is really necessary. In one of the other cases where the children were heard and the certificate was issued the order was an interim order, which involved two children, and it is questionable whether the children were genuinely heard in this case. ${ }^{111}$ In the final case the judge upheld the views of the child, ultimately permitting the child to live with the abducting parent in the State of refuge, Poland, but required that the child first have one school year in Ireland with the left-behind parent. ${ }^{112}$

\begin{tabular}{|l|r|r|r|r|}
\hline \multirow{2}{*}{ Method of hearing the child } & \multicolumn{2}{|c|}{ Decision of the court in the State of origin } & \multirow{2}{*}{ Total } \\
\cline { 2 - 5 } & $\begin{array}{c}\text { Certificate } \\
\text { issued }\end{array}$ & $\begin{array}{c}\text { Return not } \\
\text { required }\end{array}$ & unknown & \multicolumn{1}{c|}{ Total } \\
\hline Yes - heard 'indirectly' & 4 & 9 & 1 & 14 \\
No & 22 & 15 & 1 & 38 \\
Unknown & 3 & 4 & 7 & 14 \\
'Opportunity' given & 3 & 0 & 1 & 4 \\
Total & 32 & 28 & 10 & 70 \\
\hline
\end{tabular}

Figure 9: hearing the child and the final decision

\footnotetext{
${ }^{109}$ Belgium reported a difficulty in accessing video-conferencing facilities for abduction cases. In Belgium video-conferencing is available for criminal cases but not civil cases and the procedure to organise it is complex. Portugal noted that even though they had requested video-conferencing facilities to be made available under the urgent procedure so that they could hear the abducting party in the Netherlands that the Netherlands could not offer a slot within 8 weeks of the request. See the country reports for Belgium and Portugal.

${ }^{110}$ In this case the order has never been enforced, and the child has been moved several times by the father in order to avoid enforcement. She is now in a State outside the EU (information provided by a local researcher and a lawyer, please see the English and Welsh country report for further details).

${ }^{111}$ Minister for Justice and Equality acting as Central Authority $v$ M.F and anor [2015] IEHC 538. The Irish judge just referred to a Latvian report to satisfy the requirements of Art 42 indicating that a full welfare hearing would not in fact take place until the children returned to Ireland (see the Country Reports, supra $\mathrm{n}$ 7, for more details).

112 O.K $v$ K [2011] IEHC 360.
} 
In three of the cases where an opportunity was given, but this was not acted upon, the court issued an Article 42 certificate requiring the return of the child. It is questionable whether the 'opportunity' given in Aguirre Zarraga was a genuine opportunity, ${ }^{113}$ however because the certificate accompanying the judgment is currently unreviewable, the judge in the State of origin is free to assess whether an 'opportunity' has been given, with no clear guidelines on whether this requirement has actually been fulfilled.

\section{(b) Reasons for not hearing the child}

\section{(i) Age and maturity of the child}

The age and degree of maturity of the child could justify why these children were not being heard. The cases where the child was heard, or observed, concerned children aged between two and fourteen. However out of the 57 cases where the age of the child was identifiable only 23, or 40 per cent, of the children were five years of age and under, and therefore could in some cases be correctly regarded as not having the requisite age or maturity where it would be appropriate to hear the child. ${ }^{114}$ Age alone should not be decisive, though, particularly in welfare proceedings and States should ensure that children are heard or observed through suitable mechanisms, ${ }^{115}$ and judges read reports on the child's family situation, produced by relevant practitioners. At the other end of the spectrum 33 children were aged between six and fifteen. ${ }^{116}$ It is suggested that these children do have the requisite age to be heard. Courts can only determine whether children have the maturity to be heard if they hear the child through an appropriate mechanism, and at that stage the judge can decide how much weight to give to the child's views. ${ }^{117}$ Courts have a duty under international law and EU law to hear children in

\footnotetext{
${ }^{113}$ Aguirre Zarraga supra n 58, and see supra $\mathrm{n} 105$ above.

${ }^{114}$ In Re W (Abduction: Child's Objections) [2010] EWCA Civ 520 a 6 year old child was considered to have age and maturity for their objection to return to be taken into consideration for non-return. Cafcass regard a child as having the age and maturity to be heard from the age of 6 , in Hague Convention proceedings (information provided at an interview on 6 October 2015).

115 The UN Committee on the Rights of the Child has indicated that all children, including infants, should be heard through a mechanism that is appropriate for their age, see UN Committee on the Rights of the Child, General Comment no. 7: Implementing Child Rights in Early Childhood (2005) CRC/C/GC/7/Rev 1, 6-7. See also C Fenton-Glynn, "The Child's Voice in Adoption Proceedings: A European Perspective" (2014) International Journal of Children's Rights 135, 140-41.

${ }^{116}$ In addition there is a case where the exact age of the child is unknown, but the child was at least seven years old, the child was not heard and an Art 42 certificate was issued. This is clear because the date of the abduction was seven years before the Art 11(8) proceedings. It took the father five years to initiate Hague proceedings in Poland (it is suggested he did complain of the abduction earlier but did not utilise the Hague Convention), so it is unclear why Art 11(8) applied as jurisdiction is lost under Art 10 if the parent does not make a Hague application within a year of them knowing where the child is (the child was with her grandparents in Poland). ( $X$ c $Y$ (2009), for further information see the Belgium country report).

${ }^{117}$ See for example, Re M (Republic of Ireland)(Child's Objections)(Joinder of Children as Parties to Appeal) [2015] EWCA Civ 26 where Black LJ indicated, in relation to a Hague case, that it should be presumed that
} 
order to make an appropriate welfare assessment, therefore where judges take a decision not to hear children they should have to give sufficient reasons for this.

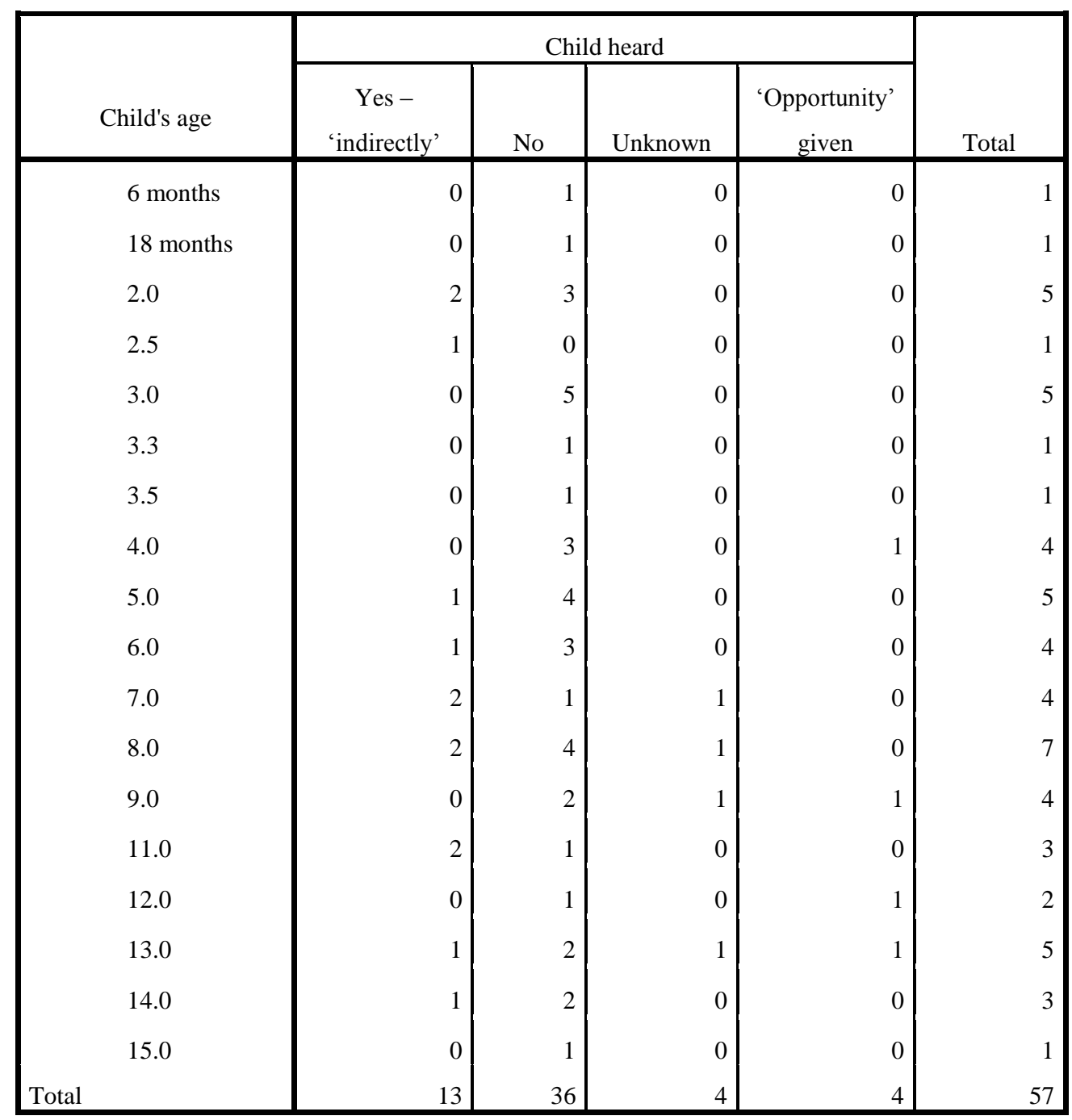

Figure10: Age of the child

The findings indicate that children as old as 15 were not heard even when the reason for their non-return was based on the child's objection. ${ }^{118}$ Even if consideration is given to the fact that some Member States will only hear the child from above the age of $12,{ }^{119}$ this would still leave

children have the age and maturity to be heard, they should be heard and then judges should exercise their discretion when determining how much weight should be given to these views and whether they should be decisive.

${ }^{118}$ Italy country report - CA No 149/12. In a Portuguese case (207DE2010) the child was aged 14 when abducted to France. During Hague proceedings the French court refused to return the child based on the child's objections. The Portuguese court then ordered the return of the child under Art 11(8) Brussels IIa and the Portuguese judge did not hear the child, much to the concern of the French Central Authority. The implementation of the order was delayed (because the French court ordered further psychological reports) to the extent that the child is now 18 years old and remains in France.

119 These national laws do not comply with the Convention on the Rights of the Child as it is inflexible to automatically presume that children under a certain age are incapable of expressing their views in an appropriate way. 
9 children over the age of 12 who were not heard. Giving the child the opportunity to be heard does not mean that their view has to be followed. The courts have discretion as to the weight they give to the child's views, and therefore at the very least these children should have had the opportunity to be heard, particularly as it is a requirement under Article 42.

\section{(ii) Hearing the child in another Member State}

There are more obstacles to gathering evidence on a child who is in another Member State, and hearing a child when they are in that State, but it is clear that this is possible. In some cases children can be heard via video-link, in other cases welfare officers in the State of refuge can produce reports on the child and in other cases welfare officers from the State of origin will already have written reports as part of the ongoing custody proceedings or will travel to the State of refuge to write their report. In some English cases it has been necessary for a Cafcass officer or Children's Guardian to travel to the State of refuge to hear the child and observe them there. In these circumstances an officer would aim to go abroad and conduct all the necessary enquiries over a 2-3 day period. ${ }^{120}$ Children of all ages are observed in their family surroundings. Older children are seen independently. The aim is to see them in a variety of contexts, such as school and their home as well as in a neutral environment such as a café in order to put the child at ease, try to get an accurate understanding of their home life and uncover the child's true feelings. ${ }^{121}$ Although this is a short period of time, the interviewees indicated that they would be unlikely to spend much more time than this with a child in national proceedings, due to pressure from judges to deal with cases quickly. ${ }^{122}$ The one key difference, between national and international cases, is that if later on the Cafcass officer feels unsure about something and wants to double check a particular point they are unable to do this in cross-border cases. They only get one chance to gather all the information necessary for their report. $^{123}$

Cafcass officers also indicated that in certain circumstances, the gathering of evidence abroad might be offensive to the national social services in that State and that the authorities from the State of origin might not always be the best people to hear the child due to differences in cultural norms. ${ }^{124}$ However this has to be balanced by the need to obtain a report that meets

\footnotetext{
${ }^{120}$ Information provided at an interview on 6 October 2015. A response to the solicitors' questionnaire also indicates that it has been possible for children to be heard through Cafcass in Art 11(8) proceedings and that Cafcass have travelled abroad where necessary.

${ }^{121}$ Information provided at an interview on 6 October 2015.

122 Ibid.

${ }^{123} \mathrm{Ibid}$.

${ }^{124}$ Ibid.
} 
the evidential requirements in the State of origin. The relevant authorities have greater awareness of what judges in their State need from their reports and judges have more experience of reading reports produced by their own authorities. Therefore it is probable that reports made by the authorities in the State of the judge making the decision are generally likely to be more useful in assisting the judge when reaching a welfare decision. Despite the fact that it was recognised that there are downsides to gathering evidence abroad in order to carry out a full welfare enquiry, the Cafcass officers indicated that this was possible, and therefore they could see no reason for an amendment to the Regulation in this respect. ${ }^{125}$ In short therefore there is no need to issue Article 42 certificates in relation to summary returns in order to hear the child. Instead judges in Article 11(6)-(8) Brussels IIa proceedings should make use of the tools available, such as the Taking of Evidence Regulation, and Member States should be willing to let the relevant authorities gather appropriate information in order to ensure that the principle of the best interests of the child is upheld in these sensitive cases.

\section{(iii) Impact of the abducting parent on the child's right to be heard}

Another possible reason why a child has not been given the opportunity to be heard is because the abducting parent has chosen not to cooperate in the proceedings; a behaviour that has serious consequences for the child's right to be heard, even though this behaviour is permitted. ${ }^{126}$ This behaviour places the court in a difficult position. If the court makes efforts to hear the child this risks delaying the proceedings, and if it does not issue an Article 42 certificate as a result of the abducting parent's negative behaviour then this has a significant impact on the right to a fair trial and right to family life of the left-behind parent.

\section{(c) The Article 42 certificate}

The Article 42 certificate at present cannot be reviewed which is unfortunate because these certificates are often issued incorrectly, as can be seen by the fact that in the 38 cases where the child was clearly not heard, the courts still issued the Article 42 certificate. The weakness

\footnotetext{
125 Ibid.

${ }^{126}$ Art 47 of the EU Charter of Fundamental Rights (EU Charter) provides a right to an effective remedy before a tribunal, and entitlement to a fair and public hearing. However, if a person chooses not to participate in those proceedings, when invited to do so, then this does not mean that the proceedings cannot or should not continue. This was evident in D $N$ and $D$ (By her Guardian ad Litem, ) [2011] EWHC 471 (Fam).
} 
lies in Point 11 of the certificate that asks the court to affirm that: 'The children were given an opportunity to be heard, unless a hearing was considered inappropriate having regard to their age or degree of maturity'. A simple affirmation is not sufficient to protect the right of the child to be heard. Instead the certificate should state what the opportunities were, when they were offered; and if the child did not take the opportunity to be heard the reasons why they did not should be stated clearly. Similarly where the judge decided it was inappropriate to hear the child, they should have to give reasons indicating why they reached this decision. It is extremely important that both the certificate and the judgment contains this information, currently this is not happening. There should be minimum standards that apply to the judgment and the certificate. Imposing the need for clarity upon the courts should improve the protection of this fundamental right.

\section{(d) Conclusion}

The overall data indicates that the child was definitely heard in only 20 per cent of cases. When looking at cases where the child was six years or over (in cases where the ages are known), only nine out of 33 children, or 27 per cent, of these children were heard. This means that on the basis of the information provided 72 per cent of children aged six and over were not heard. ${ }^{127}$ Only four children aged 5 or younger out of a total of 24 children in that age group were heard, 16 of these children fall within the ages of $3-5$ years. When the Regulation was initially amended to support the right of the child to be heard this was greeted with understandable optimism. ${ }^{128}$ However this study shows that the right of the child to be given the opportunity to be heard is not being protected. It is understood that the right for the child to be heard in such difficult circumstances should be handled with great sensitivity, however automatic age requirements should not be created. Instead the focus should be on the provision of the necessary tools, environment and suitable training to allow the child's voice to be heard, where appropriate in relation to their maturity, by the correct people and with the minimum of harm to the child. Just as important as hearing the child is the child's understanding of the proceedings, the opportunity for a third party to explain to the child exactly what is happening to them and allow the child to ask questions with the knowledge that the child will get an impartial answer. If the child has the capacity to understand the situation and is able to express a view, then this should be respected, by allowing the child to express those views. However,

${ }^{128}$ K Trimmings, supra $\mathrm{n} 17$, Chapter 7. 
not all children will want to accept the opportunity to be heard as they may not want to be seen to be effectively taking sides. This is a burden that a child should not have to carry and the decision not to express a view should be respected.

Onus must be placed on the State of origin to train those who will hear the child so that they have the skills to enquire without harming the child. They should also have a proper understanding of how Brussels IIa Article 11(6)-(8) operates. Judges should explain in their judgment, and within an Article 42 certificate, by what method, where and when they gave the child the opportunity to be heard. Where the child was not heard the judgment and the certificate should justify why the child was not given the opportunity to be heard, and this should not be justified on the basis of age alone. There should be a reasonable explanation as to why a judge thought the child was too young to be heard if this was the reason why the judge deemed it to be inappropriate.

\section{Hearing the abducting parent}

The information received on hearing the parents is not as complete as the information provided on proceedings in general. The case law, where available, suggests that it is difficult to hear the abducting parent in these proceedings. There are 19 cases where the parent was definitely heard through some mechanism (30 per cent), and ten cases where the parent was given an 'opportunity' to be heard but was ultimately not heard. This results in at least 27 cases where the abducting parent was not heard.

\begin{tabular}{|c|c|c|c|c|c|c|c|}
\hline \multirow[b]{2}{*}{ Member State } & \multicolumn{6}{|c|}{ Was the abducting parent heard? } & \multirow[b]{2}{*}{ Total } \\
\hline & $\begin{array}{l}\text { In person in } \\
\text { court }\end{array}$ & Indirectly & $\begin{array}{l}\text { Yes-method } \\
\text { unknown }\end{array}$ & $\begin{array}{l}\text { Opportunity } \\
\text { given }\end{array}$ & No & Unknown & \\
\hline Austria & 0 & 0 & 0 & 0 & 0 & 1 & 1 \\
\hline Belgium & 1 & 1 & 1 & 1 & 2 & 1 & 7 \\
\hline Czech Republic & 0 & 0 & 0 & 0 & 1 & 0 & 1 \\
\hline France & 0 & 0 & 0 & 2 & 0 & 0 & 2 \\
\hline Germany & 2 & 2 & 0 & 0 & 0 & 2 & 6 \\
\hline Greece & 0 & 0 & 0 & 0 & 0 & 1 & 1 \\
\hline Hungary & 1 & 0 & 0 & 0 & 0 & 0 & 1 \\
\hline Ireland & 0 & 2 & 0 & 1 & 0 & 2 & 5 \\
\hline Italy & 1 & 0 & 0 & 2 & 10 & 4 & 17 \\
\hline
\end{tabular}




\begin{tabular}{l|l|l|l|r|r|r|r|}
\hline Latvia & 0 & 1 & 0 & 0 & 0 & 0 & 1 \\
Luxembourg & 1 & 0 & 0 & 0 & 0 & 0 & 1 \\
Portugal & 0 & 1 & 0 & 0 & 1 & 1 & 3 \\
Romania & 3 & 0 & 0 & 0 & 2 & 5 \\
Slovenia & 0 & 0 & 0 & 1 & 0 & 1 \\
Spain & 0 & 0 & 0 & 1 & 0 & 2 & 3 \\
UK-England \& Wales & 1 & 3 & 0 & 4 & 2 & 1 & 11 \\
Total & 7 & 13 & 11 & 17 & 66 \\
\hline
\end{tabular}

Figure11: Hearing the abducting parent

The problem with this is that an 'opportunity' to be heard is not being treated consistently throughout the EU. In some cases clear opportunities are given but the parent refuses to cooperate. This may be because they are given poor legal advice, they do not have access to legal aid, they do not believe that the court in the State of origin has jurisdiction, they no longer trust the courts and the justice system in that State ${ }^{129}$ (or the justice system in general) or a combination of these factors. There seems to be an idea that if you ignore the problem for long enough it will disappear but that is not necessarily the case. ${ }^{130}$ In these cases attempts have been made to hear parents either via video-link, ${ }^{131}$ or through their solicitor. Where the parent has still failed to cooperate, despite numerous chances, judges have gone on to make a decision in the absence of the parent and their representative (if they have one). ${ }^{132}$ In these cases the approach taken by the judge is understandable as the abducting parent has effectively negated their right to be heard through lack of cooperation. ${ }^{133}$ The ECtHR has held that where an applicant has clearly waived their right to be heard, then to continue the trial in their absence is not a violation of Article 6 ECHR. ${ }^{134}$ Unfortunately for the child, this means that any

\footnotetext{
${ }^{129}$ Information provided suggests that the mother in Bradbrooke supra $\mathrm{n} 33$, considered that the authorities were out to get her, and she could not understand why the Belgian courts still had jurisdiction when the Polish courts had issued a Hague non-return order. Given the situation that followed it is likely that the mother has now completely lost faith in the justice system.

${ }^{130}$ Information provided by solicitors, in response to the solicitors' questionnaire, indicates that abducting parents rarely engage in, or cooperate with, Art 11(6)-(8) Brussels IIa proceedings. They also ignore the order which is subsequently served on them and do not comply with it. Enforcement proceedings have to be commenced in the State of refuge, at which stage the abducting parent instructs solicitors to challenge the proceedings. It is unlikely that the order will be enforced.

${ }^{131}$ R.G. $\mathrm{N}^{\circ}: 2014 / \mathrm{JR} / 73$ et $\mathrm{N}^{\circ}: 2014 / \mathrm{FA} / 113$.

${ }^{132}$ See for example, ibid, $D v N$ and D (By her Guardian ad Litem, ) [2011] EWHC 471 (Fam) and Re A [2006] EWHC 3397 (Fam).

${ }^{133}$ Under Art 6 of the European Convention on Human Rights (ECHR) and Art 47 of the Charter of Fundamental Rights of the European Union OJ C 364/1.

${ }^{134}$ For example App No 28796/05, Battistiv France 12 December 2006 (French only). This case related to a criminal trial so the threshold is higher and Art 6(3) applies. In civil proceedings only Art 6(1) applies so it is arguably easier for an applicant to waive their right through failure to cooperate. Art 47 of the Charter refers to an entitlement to a fair trial and to the possibility of being advised, defended and represented, indicating that the defendant can waive their rights.
} 
decisions are not necessarily in their best interests, and where a summary return is ordered the instability for the child is prolonged. In other cases almost no effort was made to hear the parents either because the judge seemed to be taking an easy option, ${ }^{135}$ or because the court refused to hear the parent via any mechanism other than in person. ${ }^{136}$ Service of documents alone might be considered as an 'opportunity', by some judges, in the sense that the parties were aware of the proceedings so they could be heard. This should be deemed insufficient for these purposes, as the party may not have received the documents if they were served at the wrong address and this cannot be reviewed at the enforcement stage, unlike in Brussels I (revised). ${ }^{137}$

This divergence of what is currently being considered an 'opportunity' across Member States is unacceptable, questions the effectiveness and reliability of the certificate and should not be allowed to continue. All judges have to do is state "yes" to points 11, 12 and $13 .{ }^{138}$ There is then a valid certificate which makes the judgment it accompanies automatically enforceable and is non-reviewable, ${ }^{139}$ regardless of the approach taken by the judge. ${ }^{140} \mathrm{~A}$ revised Regulation should include stricter requirements for the findings in the judgment and the completion of the certificate. The judge should not only have to state whether or not the parties were given an opportunity to be heard, but they should also have to state what this opportunity entailed and what attempts were made to hear the parties. ${ }^{141}$ Similarly judges should have to state how they took account of the reasons underlying the Hague non-return order, ${ }^{142}$ and where they considered it was inappropriate to hear the child they should have to give their reasons for reaching this decision. ${ }^{143}$ The provision of this additional, important, information should increase the quality of judgments, the merit of certificates and mutual trust as the enforcing State will be able to see what efforts the judge has made. ${ }^{144}$

\footnotetext{
135 TQ13P00079/ZC14P00064 EWHC (Fam) 4 July 2014 (Unreported), and see supra n 64.

${ }^{136}$ Aguirre Zarraga supra n 58, where the mother offered to be heard by video-link but this was refused by the Spanish courts.

${ }^{137}$ EU Regulation No 1215/2012 of the European Parliament and of the Council of 12 December 2012 on jurisdiction and the recognition and enforcement of judgments in civil and commercial matters [2012] OJ L351/1, Art 46.

138 Annex IV, Brussels IIa.

139 Art 43.

${ }^{140}$ Weller has argued that 'control is only effective if exercised by someone other than the one to be controlled.' This could suggest that the control mechanism in Art 42 is ineffective as it is being carried out by the judge issuing the decision (Weller, supra $\mathrm{n} 54,71$ ).

${ }^{141}$ Annex IV, point 12 .

${ }^{142}$ Annex IV, point 13.

143 Annex IV, point 11.

${ }^{144}$ Although this is clear from some decisions, this is not always the case so this additional information is necessary.
} 
When analysing whether abducting parents were heard it is interesting to look at the outcome of the Article 11(6)-(8) proceedings. In fact where parties were given an 'opportunity' to be heard but did not cooperate an Article 42 certificate was issued in 70 per cent of cases.

\begin{tabular}{|c|c|c|c|c|c|c|}
\hline \multirow{2}{*}{\multicolumn{3}{|c|}{ Abducting parent heard }} & \multicolumn{3}{|c|}{ Decision of the court of origin } & \multirow[b]{2}{*}{ Total } \\
\hline & & & \multirow{2}{*}{$\begin{array}{l}\begin{array}{c}\text { Certificate } \\
\text { issued }\end{array} \\
\\
1\end{array}$} & \multirow{2}{*}{$\begin{array}{l}\begin{array}{l}\text { Return not } \\
\text { required }\end{array} \\
5\end{array}$} & \multirow{2}{*}{$\begin{array}{r}\text { unknown } \\
1\end{array}$} & \\
\hline & In person in court & Number & & & & 7 \\
\hline & & Per cent & $14.3 \%$ & $71.4 \%$ & $14.3 \%$ & $100.0 \%$ \\
\hline & \multirow[t]{2}{*}{ Indirectly } & Number & 6 & 7 & 0 & 13 \\
\hline & & Per cent & $46.2 \%$ & $53.8 \%$ & $0.0 \%$ & $100.0 \%$ \\
\hline & \multirow[t]{2}{*}{ Yes-method unknown } & Number & 0 & 1 & 0 & 1 \\
\hline & & Per cent & $0.0 \%$ & $100.0 \%$ & $0.0 \%$ & $100.0 \%$ \\
\hline & \multirow[t]{2}{*}{ Attempted } & Number & 8 & 3 & 0 & 11 \\
\hline & & Per cent & $72.7 \%$ & $27.3 \%$ & $0.0 \%$ & $100.0 \%$ \\
\hline & \multirow[t]{2}{*}{ No } & Number & 7 & 8 & 2 & 17 \\
\hline & & Per cent & $41.2 \%$ & $47.1 \%$ & $11.8 \%$ & $100.0 \%$ \\
\hline & \multirow[t]{2}{*}{ Unknown } & Number & 7 & 3 & 7 & 17 \\
\hline & & Per cent & $41.2 \%$ & $17.6 \%$ & $41.2 \%$ & $100.0 \%$ \\
\hline \multirow[t]{2}{*}{ Total } & & Number & 29 & 27 & 10 & 66 \\
\hline & & Per cent & $43.9 \%$ & $40.9 \%$ & $15.2 \%$ & $100.0 \%$ \\
\hline
\end{tabular}

Figure 12: hearing the abducting parent and final decision

The information collected suggests that courts are less likely to issue an Article 42 certificate where the parties have been heard. Given that one purpose of the certificate is to protect the parties' rights, including the right to be heard, in relation to the abolition of exequatur this finding is slightly obtuse. One positive that could be taken from this finding is that abducting parents are generally better off where they cooperate with the courts in the State of origin during these proceedings. ${ }^{145}$ These findings should encourage practitioners to tell parties to cooperate rather than giving them poor legal advice, essentially telling them to ignore the proceedings. Not only is the abducting parent more likely to get the desired result but it is also better for the

\footnotetext{
${ }^{145}$ It has been suggested that some parents do not cooperate because they know that they have no chance of success. Although this might have been the case in Re A supra n 60, the opposite was true in Bradbrooke supra $\mathrm{n} 33$, where if the mother had cooperated the child would have been permitted to remain in Poland. In either case the best outcome will be reached where all parties are involved and cooperate in proceedings.
} 
child as stability will be regained sooner and the judge will be able to make a better assessment of the child's family situation if all the parties have been heard via some mechanism. It could also be seen as supporting mutual trust, in the sense that when both judges have access to the relevant information they reach the same result (although one when making a summary decision and the other when giving a full welfare decision). Therefore in addition to requiring further information in the judgment and the certificate, a revised Regulation should try and increase facilities for hearing parties.

One key finding over the course of this study has been the lack of ready availability of video-conferencing equipment. It has been reported that the facilities can be very difficult to access, ${ }^{146}$ or there can be long delays. ${ }^{147}$ A Member State that has good video-conferencing facilities is Latvia. They have at least one set of equipment in each court building, as a result of some funding they received. ${ }^{148}$ Unfortunately, this useful technology has not been used in civil proceedings thus far. As delegates have reported many problems relating to hearing parties through video-conferencing equipment, either because of hurdles at their end or lengthy delays in other Member States, it might be useful to create an additional mechanism for hearing abducting parents. One method of doing this could be through Central Authorities. ${ }^{149}$ A revised Regulation, or clear guidance in a Practice Guide, could require Central Authorities to have a room with video-conferencing equipment. This would create a safe place for abducting parents to go and be heard by the judge in the other Member State. The other benefit of this is that a representative from the Central Authority, who should be a practising lawyer, ${ }^{150}$ will be able to give some legal advice to abducting parents, ${ }^{151}$ inform them that the courts in the State of origin do still have jurisdiction, that they are more likely to get a favourable result if they speak to the judge and whether they are likely to qualify for legal aid. Although Central Authorities should not be overworked, this could easily operate on a scheme where abducting parents facing Article 11(6)-(8) proceedings are entitled to 30 minutes of legal advice, ${ }^{152}$ as a

\footnotetext{
${ }^{146}$ Interview 15 May 2015.

147 See supra $\mathrm{n} 105$.

${ }^{148}$ Interview 16 June 2015.

${ }^{149}$ For information on minimum requirements for Central Authorities in the context of maintenance see L Walker, Maintenance and Child Support in Private International Law (Hart Publishing, 2015) 236-244.

${ }^{150}$ All Central Authorities should have at least one trained lawyer, either in house or as part of the wider department.

${ }^{151}$ As indicated by Art 47 of the Charter. It is still open to abducting parents to seek independent legal advice (where they can afford to do so) and/ or instruct a solicitor to represent them in court if they prefer this option. ${ }^{152}$ As there seems to have been a relatively low number of these proceedings over ten years, this should not create an overly burdensome requirement. Art 47 of the Charter indicates that Member States should make sufficient legal aid available in order to ensure effective access to justice.
} 
minimum. ${ }^{153}$ If this initial outlay, which should be fairly minimal, means that cases can be dealt with in one hearing instead of five or six this should save the State money in the long run. The availability of this mechanism should increase cooperation, as abducting parents tend to trust the authorities in the State of refuge more than the authorities in the State of origin, ${ }^{154}$ and ensure that appropriate legal advice is available.

\section{Hearing the left-behind parent}

Unsurprisingly, the left-behind parent was heard much more frequently than the abducting parent. The information received indicates that the left-behind parent was heard in 57 per cent of cases.

\begin{tabular}{|c|c|c|c|c|c|}
\hline & \multirow{2}{*}{ Member State } & \multicolumn{3}{|c|}{ Was the left behind parent heard? } & \multirow[b]{2}{*}{ Total } \\
\hline & & Yes & No & Unknown & \\
\hline & Austria & 0 & 0 & 1 & 1 \\
\hline & Belgium & 6 & 0 & 1 & 7 \\
\hline & Czech Republic & 1 & 0 & 0 & 1 \\
\hline & France & 2 & 0 & 0 & 2 \\
\hline & Germany & 4 & 0 & 2 & 6 \\
\hline & Greece & 1 & 0 & 0 & 1 \\
\hline & Hungary & 1 & 0 & 0 & 1 \\
\hline & Ireland & 4 & 0 & 1 & 5 \\
\hline & Italy & 4 & 6 & 7 & 17 \\
\hline & Latvia & 1 & 0 & 0 & 1 \\
\hline & Luxembourg & 0 & 1 & 0 & 1 \\
\hline & Portugal & 0 & 2 & 1 & 3 \\
\hline & Romania & 3 & 0 & 2 & 5 \\
\hline & Slovenia & 1 & 0 & 0 & 1 \\
\hline & Spain & 1 & 0 & 2 & 3 \\
\hline & UK-England \& Wales & 10 & 0 & 1 & 11 \\
\hline Total & & 39 & 10 & 17 & 66 \\
\hline
\end{tabular}

Figure 13: hearing the left-behind parent

\footnotetext{
${ }^{153}$ Some firms operate on this system in the UK, particularly in family law proceedings, to help potential clients understand what their options might be http://www.bannerjones.co.uk/page/-assessment-information-meeting accessed 12 January 2016.

154 This came across during the interviews in Latvia and Belgium and from correspondence with an abducting parent. This is also true the other way, where the left-behind parent tends to have limited trust in the authorities in the State of refuge (interview 13 February 2015). For case law examples see Re C (Jurisdiction and Enforcement of Orders Relating to a Child) [2012] EWHC 907 (Fam) alongside Cooper c Cooper R.G. No: 11/3804/A, 14 March 2012 and AFv T and A (a child, by his Children's Guardian) [2011] EWHC 1315 (Fam). A reason for this, in addition to the ones referred to above is that sometimes the abducting parent is also facing criminal proceedings in the State of origin which also means they are not inclined to cooperate. In Belgium they tend to issue fines and a common approach when issuing Art 11(8) decisions accompanied by an Art 42 certificate is to suggest that the abducting parent will be fined $€ 500$ a day for every day that they do not return with the child. This seems to be counter-productive as none of the parents can actually afford this and rather than acting as an incentive to return it appears to alienate the abducting parent further. See also Weller, supra $\mathrm{n}$ 54,66 .
} 
This finding differs from the preliminary project findings, ${ }^{155}$ but it is more in line with original expectations. The earlier data could have been skewed slightly by the detailed response from the Italian Central Authority. The Italian approach, where the left-behind parent is often not heard, is not reflected across the Member States. ${ }^{156}$ The overall findings are much healthier and show greater protection of the right to be heard. One would expect the left-behind parent to be heard as the Article 11(6)-(8) proceedings take place in the State in which they are resident, they initiated the proceedings and therefore they have no reason not to cooperate.

\section{The reasons for and evidence underlying the non-return order}

In the majority of the cases the court in the State of origin took account of the reasons for and evidence underlying the Hague non-return order.

\begin{tabular}{|c|c|c|c|c|c|c|}
\hline & \multirow[b]{2}{*}{ Member State } & \multicolumn{4}{|c|}{ Approach of the court in the State of origin } & \multirow[b]{2}{*}{ Total } \\
\hline & & Yes & No & Mixture & Unknown & \\
\hline & Austria & $\overline{0}$ & 0 & $\overline{0}$ & 1 & 1 \\
\hline & Belgium & 6 & 1 & 0 & 0 & 7 \\
\hline & Czech Republic & 0 & 0 & 0 & 1 & 1 \\
\hline & France & 2 & 0 & 0 & 0 & 2 \\
\hline & Germany & 2 & 0 & 0 & 4 & 6 \\
\hline & Greece & 1 & 0 & 0 & 0 & 1 \\
\hline & Hungary & 1 & 0 & 0 & 0 & 1 \\
\hline & Ireland & 3 & 0 & 0 & 2 & 5 \\
\hline & Italy & 14 & 0 & 0 & 3 & 17 \\
\hline & Latvia & 1 & 0 & 0 & 0 & 1 \\
\hline & Luxembourg & 1 & 0 & 0 & 0 & 1 \\
\hline & Portugal & 2 & 0 & 1 & 0 & 3 \\
\hline & Romania & 2 & 1 & 0 & 2 & 5 \\
\hline & Slovenia & 0 & 0 & 0 & 1 & 1 \\
\hline & Spain & 2 & 0 & 0 & 1 & 3 \\
\hline & UK-England \& Wales & 7 & 2 & 0 & 2 & 11 \\
\hline Total & & 44 & 4 & 1 & 17 & 66 \\
\hline
\end{tabular}

Figure 14: Did the court in the State of origin take account of the reasons behind and the evidence underlying the Hague non-return order?

In one of the cases where the court did not take account of the reasons for the Hague non-return order this is because the reasons were unclear from the documentation which only referred to Article 13 and not a specific provision. ${ }^{157}$ Where this happens it is impossible for the judge to

\footnotetext{
${ }^{155}$ See Beaumont et al, supra $\mathrm{n} 8,131$.

${ }^{156}$ In Italy the parties are notified of the proceedings through a written note which is delivered to the last known address, but this does not need to follow the formalities for service of documents (see the Italian report for more details). As long as somebody at the address takes the document then it is presumed that it has been properly served. If one of the parties wants to argue that they did not receive notice of the proceedings, the burden of proof lies on them to show that the document was not actually delivered.

${ }^{157}$ It has been reported that Polish orders do not always contain the reasons for non-return.
} 
take account of the reasons behind the non-return order. Judges have also had problems identifying whether the non-return was on the basis of Article 3 or Article 13(1)(a), consent. ${ }^{158}$ In the case where it is given as a 'mixture' this is based on information given by the French Central Authority. The Central Authority explained that this was because the judgment indicates that the judge has taken account of some of the reasons and refers to later developments in Portugal, however the Portuguese judge did not hear the child who was 14 years old, had been heard by the French authorities, and expressed her fears of being returned to Portugal. ${ }^{159}$ The information indicates that judges are generally taking account of the reasons for non-return, as far as they can, but this can be hindered by unclear judgments or a failure to hear all the parties during the Article 11(6)-(8) proceedings.

\section{Details of measures to ensure the protection of the child}

The final component of the certificate is that it should contain details of any protective measures taken. Unlike the other parts where judges can currently just state "yes" or "no", it is clear from the text of the Regulation that the judge should include the details in the certificate: "the certificate shall contain details of such measures". ${ }^{160}$ It is unclear whether this is happening as access to certificates is limited, because they are not appended to the reported judgments, and information was not sought on this aspect in the questionnaires. One certificate that we have access to indicates that this might not be happening, because although some protective measures were given in the order the certificate just states "YES", at point $14 .{ }^{161}$ The lack of information available means that no clear conclusions can be drawn on this aspect, however an overall assessment suggests that Article 42 certificates are not always completed adequately and adjustments will be needed in a revised Regulation, with the aim of making the information provided more reliable. ${ }^{162}$

\section{The ability to review the certificate}

\footnotetext{
${ }^{158}$ Eg Re SJ (a child) (Habitual Residence: Application to Set Aside) [2014] EWHC 58 (Fam). ${ }^{159}$ Response provided by the French Central Authority to the Central Authority Questionnaire. 160 Art 42.

161 TQ13P00079/ZC14P00064 EWHC (Fam) 4 July 2014 (Unreported).

${ }^{162}$ For further analysis of the abolition of exequatur see, for example, X Kramer, "Abolition of Exequatur under the Brussels I Regulation: Effecting and Protecting the Rights in the European Judicial Area" (2011) Nederlands Internationaal Privaatrecht 663, L Timmer "Abolition of Exequatur under the Brussels I Regulation: Ill Conceived and Premature" (2013) Journal of Private International Law 129 and I Viarengo, "The Enforcement of Maintenance Decisions in the EU: Requiem for Public Policy? Family Relationships and the (Partial) Abolition of Exequatur" in P Beaumont et al (eds) The Recovery of Maintenance in the EU and Worldwide (Hart Publishing, 2014) 473.
} 
The information above indicates that the Article 42 certificate is not necessarily a reliable document and therefore the inability to review the certificate is flawed. Instead the judgment referred to in the certificate should not be automatically enforceable in the State of refuge, it should be reviewable on the basis of fundamental rights. ${ }^{163}$ Where the judgment is appropriately reasoned and the certificate is completed adequately, conforming to the proposed requirements, it should be able to stand up to such a review.

\section{E. Further concerns}

The article has highlighted several issues surrounding the Article 11(6)-(8) procedure. This section will now consider some other factors linked to these issues, which may already have been touched upon briefly, in further detail.

\section{Central Authorities}

One issue has been the difficulty in tracing Article 11(6)-(8) Brussels IIa cases. This is because these cases do not need to go through Central Authorities, and the Hague decision on nonreturn can be transmitted directly to the relevant court. ${ }^{164}$ This is presumably so that in cases where custody proceedings are already ongoing, the court in the State of refuge can send the documents directly to the court already dealing with the case. ${ }^{165}$ Without taking away this possibility of direct judicial communication, it would also be useful if any documents sent were

\footnotetext{
${ }^{163}$ Although this would need to be approved unanimously by Council (Treaty on the Functioning of the European Union, Art 81(3)), so it is unlikely, it is clear that the certificate does not work in its current form and changes are needed. For arguments in favour of the need for at least fundamental rights review in intra-EU private international law cases see P Beaumont and E Johnston, "Can exequatur be abolished in Brussels I whilst retaining a public policy defence?" (2010) Journal of Private International Law 249, esp 273-279 and L Walker and P Beaumont, "Shifting the balance achieved by the Abduction Convention: The contrasting approaches of the European Court of Human Rights and the European Court of Justice" (2011) Journal of Private International Law 231, 244-249. The particular problems associated with being able to enforce Art 11(8) Brussels IIa orders in a way that is compliant with fundamental rights are addressed in Beaumont et al, supra $\mathrm{n}$ 56, at 55-61. Although the generous approach of the ECtHR to EU law fundamental rights as a result of the Bosphorus decision was confirmed as applying to the abolition of exequatur in relation to Art 11(8) Brussels IIa orders in Povse (see Beaumont et al, supra n 55, 56-61) such generosity might not be continued by the ECtHR in the light of the CJEU's blocking of the accession of the EU to the ECHR in Opinion 2/13, 18 December 2014 ECLI:EU:C:2014:2454.

${ }^{164}$ Art 11(6).

${ }^{165}$ It should be noted that this does not always happen smoothly and information provided suggests that in many cases where custody proceedings are already ongoing the left behind parent has also issued proceedings under Art 11(7) resulting in two sets of proceedings. Examples of cases that look at this issue and the question of jurisdiction within a Member State are Case C-498/14 PPU Bradbrooke v Aleksandrowicz, 9 January 2015 ECLI:EU:C:2015:3 and EE and Judge O'Donnell v JS [2013] IEHC 418.
} 
also required to be sent to the relevant Central Authorities. This would keep Central Authorities aware of proceedings, so they could continue to be involved if necessary, such as to facilitate the hearing of parties. ${ }^{166}$ In $A F$, the judge involved the Central Authorities in the Article 11(6)(8) proceedings in order to try and facilitate the hearing of the mother and child in Germany through the German Authorities. ${ }^{167}$ The continued involvement of Central Authorities during the Article 11(6)-(8) process would allow them to collect complete data on child abduction proceedings including the number of applications that resulted in Article 11(6)-(8) proceedings. This can then be reported to the Commission which will help them to complete their impact assessment, using reliable data, the next time the Regulation is to be revised. This will only be possible if Central Authorities are required to have an electronic database which collects this information. It would be preferable if the Commission designed their own database, or informed Central Authorities of the specific information they require, so that all Central Authorities can generate comparable information. ${ }^{168}$ The Central Authority personnel should then be under an obligation to provide this information to relevant bodies. The collection of this information is important if impact assessments are going to be useful and reviews are to be well informed.

In order for Central Authorities to be effective it is important that they have access to suitable resources and they are adequately staffed. If Central Authorities are utilised properly and have these resources, such as an in-house lawyer and video-conference equipment, ${ }^{169}$ they should be able to increase access to justice for the parties involved in these proceedings.

\section{Legal aid}

A clear problem with the whole process, that is not necessarily resolvable at the EU level, is the lack of availability of legal aid. Currently many Member States waive a traditional means

\footnotetext{
${ }^{166}$ See above at Section E.1, the Hague Convention of 23 November 2007 on the International Recovery of Child Support and other forms of Family Maintenance, Art 6 and Council Regulation (EC) No 4/2009 of 18 December 2008 on jurisdiction, applicable law, recognition and enforcement of decisions and cooperation in matters relating to maintenance obligations, [2009] OJ L7/1, Art 51 which set out extensive duties for Central Authorities.

${ }^{167}$ AF v T and A (a child, by his Children's Guardian) [2011] EWHC 1315 (Fam).

${ }^{168}$ In relation to maintenance see P Lortie, "Developing an Electronic Case Management and Communication System for the 2007 Hague Child Support Convention and the 2009 EU Maintenance Regulation: The iSupport Project" in P Beaumont et al (eds) The Recovery of Maintenance in the EU and Worldwide (Hart Publishing, 2014) 275 and L Walker, supra n 143, 195-98.

${ }^{169}$ See s E.1 above.
} 
and merits test in relation to Hague Child Abduction proceedings, ${ }^{170}$ and the left-behind parent automatically qualifies for legal aid. ${ }^{171}$ Unfortunately this does not continue to apply in Article 11(6)-(8) Brussels IIa proceedings, the abducting parent is not provided with legal aid in any of the proceedings (unless qualifying under the national law of that State) and legal aid for relocation proceedings is also subject to a means and merits test. ${ }^{172}$ The lack of available legal aid might be a factor in the process at any point from the initial removal to a failure to cooperate with the proceedings, if no legal advice is available. ${ }^{173}$ It is unlikely that the EU can impose an unqualified requirement to provide legal aid during Article 11(6)-(8) proceedings, outside a minimum requirement to provide initial advice, possibly for half an hour. Article 47 of the Charter suggests that legal aid should be made available for those who lack sufficient resources to the extent necessary to ensure effective access to justice. It could be argued that the cuts in England and Wales ${ }^{174}$ have been so drastic that there is not actually effective access to justice

\footnotetext{
${ }^{170}$ Hague Convention 1980, Art 26.

${ }^{171}$ Now that the EU's exclusive external competence in relation to the Hague Child Abduction Convention has been clarified by Opinion 1/13, ECLI:EU:C:2014:2303, the Commission should consider how to remove the reservations that some States have made under Art 42 of the Convention in relation to Art 26 of the Hague Convention to permit the costs of legal counsel or advisers or court proceedings in Hague Child Abduction Convention cases to be charged to the individuals concerned unless they are met by the normal legal aid provisions in that State, see http://www.hcch.net/index en.php?act=conventions. statusprint\&cid=24 (last accessed on 24 September 2015). It is anomalous that in countries without the reservation Hague proceedings are not charged for whereas Art 11(8) Brussels IIa proceedings are charged for unless the individual concerned qualifies for legal aid in that country. The following EU Member States have the reservation under Art 42 and 26 of the Hague Convention: Bulgaria, Czech Republic, Denmark, Estonia, France, Germany, Greece, Lithuania, Luxembourg, Netherlands, Poland, Slovakia, Sweden and the UK. Although the UK has the reservation, legal aid is not subject to a means test. (For the English legislation see, Civil Legal Aid (Financial Resources and Payments of Services) Regulations 2013 (SI 2013/480) Part 2 Ch 1 reg 5(1)(h)).

${ }^{172}$ For information on freedom of movement, the conflicting rights of the parties and the need for practicality and stability in relocation cases see, R Lamont, "Free movement of persons, child abduction and relocation within the European Union" (2012) Journal of Social Welfare and Family Law 231, J Herring and R Taylor, "Relocating Relocation" (2006) Child and Family Law Quarterly 517 and R George, "Practitioners' views on children's welfare in relocation disputes: comparing approaches in England and New Zealand" (2011) Child and Family Law Quarterly 178.

${ }^{173}$ In M.H.A v A.P [2013] IEHC 611[23] the Irish court requested that the lawyer representing the father make enquiries in relation to cross-border legal aid and forward the relevant documents to the mother to give her a chance to participate in the proceedings. Requesting a legal aid solicitor in Ireland to do work for someone other than their client puts additional burdens on the State. In Povse the applicants argued that they did not appeal the decision before the Italian courts because they could not access legal aid in Italy (Povse v Austria (App no. 3890/11) ECHR 18 June 2011 [54]).

${ }^{174}$ Under the Legal Aid, Sentencing and Punishment of Offenders Act 2012 (LASPO).
} 
for many litigants. ${ }^{175}$ A provision requiring the provision of initial legal advice, as a minimum standard, would help to ensure access to justice. ${ }^{176}$

It is probably impossible for the EU to insist on legal aid in relocation proceedings, which are not directly covered by the Regulation, unless they are analysed as a free movement issue. ${ }^{177}$ States should think carefully and carry out a cost benefit analysis when changing their laws on legal aid, ${ }^{178}$ particularly if they are going to make drastic cuts (like in England and Wales). It is important to think about how the decreased access to legal aid will affect people's willingness to comply with the law and participate in judicial proceedings. ${ }^{179}$ Any change in behaviour which results in decreased compliance with the law, will only increase court costs in the long run, thus having a negative effect. ${ }^{180}$ Better provision of legal aid should result in greater access to justice, and quicker resolution of proceedings which should be good for the children who are the innocent parties in these proceedings. ${ }^{181}$

\section{Lack of contact/access}

Judges in the Member State of refuge should make urgent provisional measures relating to access when the child is in that State while proceedings are ongoing. This is essential because a breakdown (often irreparable) in the relationship between the child and the left-behind parent

\footnotetext{
${ }^{175}$ C Bevan, "Self-represented litigants: the Overlooked and Unintended Consequences of Legal Aid Reform" (2013) Journal of Social Welfare and Family Law 43, 45 and 47-50, C Denver, N Balmer, P Pleasence, "When Legal Rights are not a Reality: Do Individuals know their rights and how can we tell?" (2013) Journal of Social Welfare and Family Law 139, 140, http://www.theguardian.com/law/2015/sep/13/demand-for-free-help-almostdoubles-since-cuts-to-legal-aid and http://www.theguardian.com/law/2014/jul/29/legal-aid-family-courtsbreaking-point-lawyers, accessed 24 September 2015. See also Airey v Ireland (No 1) (App 6289/73) 1980 2 EHRR 305, where the ECtHR found there was a violation of Art 6 because there was no legal aid available for divorce. The State argued that the litigants can self-represent, however the ECtHR rejected this on the basis that the rights should be effective and not illusory. It is unclear how this decision fits with current policy, as a large number of litigants now have to self-represent.

${ }^{176}$ Legal aid must be provided in all child support applications made under the Maintenance Regulation, Art 46. This provision made it into the Regulation as a result of an agreement made internationally in The Hague (Hague Convention of 23 November 2007 on the International Recovery of Child Support and other forms of Family Maintenance, Article 15).

${ }^{177}$ See R Lamont, supra $\mathrm{n}$ 76. An in-depth analysis of this point is outside the scope of the current article. ${ }^{178} \mathrm{G}$ Cookson, "Analysing the economic justification for the reforms to Social Welfare and Family Law Legal Aid" (2013) Journal of Social Welfare and Family Law 21.

${ }^{179}$ Studies indicate that there is a "greater likelihood of adjournments and relisting in cases involving unrepresented parties as a consequence of self-represented litigants [sic] non-attendance." (Bevan, supra n 174, 48).

${ }^{180}$ It is also noted that the increase in litigants in person means that judges are regularly faced with litigants who are ill-prepared and therefore proceedings take at least twice as long, again resulting in increased court time and greater expense (information provided by county court judges in Brighton and Stoke) and see G Cookson, supra n 178, 29-30.

${ }^{181}$ In some situations this would simply allow parties to seek a relocation order, which would mean that there wouldn't even have to be any abduction proceedings at all.
} 
has been a regular finding in our study, ${ }^{182}$ in cases where proceedings have been ongoing for a long period of time. Decisions on urgent measures for access (contact), should fall under a revised Article 20 of Brussels IIa. The left-behind parent should be able to make use of such orders without being accused of submitting to the jurisdiction. This is essential if the relationship between the child and the left-behind parent is to be protected.

Article 11 of the 1996 Convention currently provides a useful tool to enable the courts of the country to which the child has been abducted to award interim access (contact) to the left-behind parent in the country where the child has been abducted to while the child abduction proceedings are pending. ${ }^{183}$ Given that these proceedings should be expeditious these access provisions should not be long lasting, but even in a few months it would be detrimental to the child if he or she could not have contact in person with the left-behind parent wherever that is practically possible (and of course contact by phone or internet video should always be possible).

\section{Enforcement proceedings in the State of refuge}

During the course of the study some points arose in relation to enforcement which deserve further analysis. The Latvian implementing law (amended in 2011) on the Hague Convention contains special rules on enforcement. ${ }^{184}$ The rules allow the enforcement officers (bailiffs) to collect children from school or kindergarten and place them in a protected children's home until the other parent can come and collect the children. They also require the parent seeking

\footnotetext{
${ }^{182}$ See for example, Bradbrooke c Aleksandrowicz, R.G. N ${ }^{\circ}: 2014 / J R / 73$ et $\mathrm{N}^{\circ}: 2014 / \mathrm{FA} / 113, M v T$ (Abduction: Brussels II Revised, Art 11(7)) [2010] EWHC 1479 (Fam), Povse v Austria (App no 3890/11) 18 June 2013, AF v T and A (a child, by his Children's Guardian) [2011] EWHC 1315 (Fam), D v N and D (By her Guardian ad Litem,) [2011] EWHC 471 (Fam) and Chamoun c Chachan (2011) R.G. N': 2011/AR/1040. 1831996 Convention Practical Handbook, supra n 37, 141. The 1996 Convention certainly applies within the EU when the child is habitually resident in a non-EU Contracting State to the 1996 Convention. In this context the UK Supreme Court has recently suggested that an order for interim contact may be necessary and urgent to enable the father to maintain contact with his child pending a decision on whether or not to return a child to the country of his habitual residence (Morocco) in a case where the 1980 Convention does not apply but the 1996 Convention does apply, see In the matter of J (a child) [2015] UKSC 70, para 43, although the Court rightly left this decision to the first instance judge. It is not clear whether Art 11 of the 1996 Convention applies in this context in an intra-EU case where the child is habitually resident in an EU Member State because it is not clear that such interim access orders made by the courts of the State of refuge constitute a matter "not governed by" the Brussels IIa Regulation. The Brussels IIa Recast should clarify this issue. See the discussion of this issue in the context of granting protective measures while making a return order under Art 13(1)(b) of the Hague 1980 Convention, supra nn 35-43.

184 The Law has been in force since 2006, information provided 15 June 2015. For further information see the Latvian section of the Country Reports, supra $\mathrm{n} 7$.
} 
enforcement to pay for enforcement. ${ }^{185}$ The cost of enforcement includes set fees and then other fees (dependant on the action taken) and a full deposit is required. ${ }^{186}$

In one case, ${ }^{187}$ where an Article 42 certificate was issued, the left-behind parent had qualified for legal aid in England for all proceedings, ${ }^{188}$ therefore his income must have been minimal. The Latvian authorities did not receive the certificate until after the date on which the return order was due to be enforced. They attempted to contact the applicant on a number of occasions but he did not respond so they could not proceed with enforcement. ${ }^{189}$ It is extremely important to have effective enforcement measures, however if the applicant cannot afford to pay for them it essentially deems the earlier proceedings (and outlay) pointless unless one of the States is willing to cover the costs of enforcement. The case law of the ECtHR suggests that Member State authorities' must take all steps necessary to facilitate the execution of the judgment that can reasonably be demanded in the specific circumstances of the case. ${ }^{190}$ It is unclear whether not taking any steps because the applicant has not yet paid for enforcement, will be considered to be proportionate, or whether it would be a violation of Article 8 ECHR. ${ }^{191}$ It is clear however that the non-enforcement of orders, just because an applicant is unable to cover the cost of enforcement, hinders effective access to justice across the EU.

The other issue is whether a finding of consent, means that the removal is no longer wrongful, or if appearance in public child protection proceedings and issuing residence proceedings in the State of refuge amounts to acquiescence in that court's jurisdiction. ${ }^{192}$ These issues were discussed in a Belgium - UK case,${ }^{193}$ where the English courts had refused to return

\footnotetext{
185 This is permitted under the 1980 Hague Convention, Art 26.

${ }^{186}$ There are two fixed fees: the state fee which is 2 Euro 80 cent and the expenses relating to the bailiffs action which is approximately 120 Euros. All other expenses depend on whether the applicant parent will come to collect the child (in which case they will pay for the air fare), whether the child needs to spend time at the crisis centre, if the child needs a psychologist. All these expenses depend on whether the enforcement agent or the parent takes action. If the agent has to do these things then the parent will be charged. The bailiff is an independent legal official who is not government funded and charges a deposit based on the estimated costs. Excess funds will be returned.

187 TQ13P00079/ZC14P00064 EWHC (Fam) 4 July 2014 (Unreported).

${ }^{188}$ Under the exception for Hague proceedings and then under the Legal Aid, Sentencing and Punishment of Offenders Act 2012 (LASPO) for the Art 11(6)-(8) Brussels IIa proceedings.

${ }^{189}$ Information provided on 15 June 2015. If the applicant has limited funds it is unlikely that he can pay for enforcement. See also McEleavy, supra n 65, 21.

${ }^{190}$ Ribić v Croatia (App no 27148/12) 2 April 2015.

${ }^{191}$ In some cases lack of contact with the applicant will be a hindrance to enforcement, regardless of fees, as the order may require the child to live with the applicant. This does not affect the execution of the judgment in the present case as the child was to return with the mother and live at an address unknown to the applicant (due to allegations of domestic violence) for the purpose of a full welfare hearing.

192 Under Art 10(a) Brussels IIa.

${ }^{193}$ Re C (Jurisdiction and Enforcement of Orders Relating to a Child) [2012] EWHC 907 (Fam) and Cooper c Cooper R.G. N: 11/3804/A.
} 
the child on the basis of consent. ${ }^{194}$ There were then public care proceedings brought by the local authority in England on the basis that the mother was not capable of looking after the child due to alcohol and substance abuse. The father intervened in these proceedings and issued proceedings under s8 of the Children Act. He then tried to revoke these proceedings and brought Article 11(6)-(8) Brussels IIa proceedings in Belgium. The Belgian court found that there was not actually any consent, as the mother had forged the paperwork based on previous consent given on behalf of her older daughter, ${ }^{195}$ by a person with the same surname. ${ }^{196}$ The court held that the child should return to Belgium and live with the father, partly due to the mother's alcohol and substance problems, ${ }^{197}$ and issued an Article 42 certificate. ${ }^{198}$

In the meantime several interim measures were directed by the English court in respect of the father's application under the Children Act 1989 and applications made by the Local Authority in England under the same act. ${ }^{199}$ The child moved to live with her maternal grandparents in England on 24 January 2012. ${ }^{200}$ On 3 February 2012 Hedley J made an interim care order in favour of the local authority. ${ }^{201}$ The local authority, the father, the mother and the child were all represented at the hearing. Hedley J dismissed the application made by the father for permission to withdraw his applications for a residence order and for contact. ${ }^{202}$ The decision in $\operatorname{Re} C$ concerns proceedings for the enforcement of the Article 11(8) order in England, ${ }^{203}$ which Moylan J held did not have to be enforced.

Justice Moylan's main objections to enforcing the order seemed to be that: the father did not appeal the decision of 25 November 2011, the father submitted to the English jurisdiction, therefore the English court was first seised for parental responsibility questions so lis pendens applied and the Belgian judge did not "consider it appropriate to engage in substantive communications" concerning matters of jurisdiction. ${ }^{204}$ Under the Regulation there is no requirement to appeal the decision on non-return in the State of refuge, the father can

\footnotetext{
${ }^{194} \operatorname{Art} 13(1)(\mathrm{a})$.

${ }^{195} \mathrm{Mr}$ Cooper is not her father.

${ }^{196}$ It is unclear from the judgment Cooper, supra n 193, if the two Mr Coopers are related.

${ }^{197}$ The English decision also indicates that the father had both psychiatric and physical health issues $(\operatorname{Re} C$, supra $\mathrm{n}$ 185, para 27) but this is not discussed in the Belgian decision.

198 Cooper supra n 193.

${ }^{199} \operatorname{Re}$ C supra n 193, para 17.

200 Ibid.

${ }^{201}$ Ibid, para 23.

202 Ibid.

203 Ibid.

${ }^{204}$ Ibid, para 77.
} 
proceed immediately with Article 11(6)-(8) proceedings ${ }^{205}$ as long as he does so within 3 months, regardless of whether he is pursuing proceedings in an alternative State. Further the over-reliance on the alleged habitual residence of England and Wales by the judges is unhelpful, technically Article 8 does not apply in abduction proceedings, Article 10 does. Jurisdiction can only shift, under the Regulation, when it is clear that one of the provisions in Article 10 is applicable, for example when each person, institution or body having rights of custody has acquiesced in the removal or retention, ${ }^{206}$ or the applicant has failed to issue proceedings in the State of origin within 3 months of an Article 13 Hague non-return order. ${ }^{207}$ It is unclear how the provisions in Articles 10 and 11 fit with the lis pendens provision in Article 19, which is perhaps dependent on the nature of the order under Article $11(8)^{208}$ which needs to be clarified. ${ }^{209}$

A further issue is that the certificate was defective because in relation to point 12 , the opportunity for the parties to be heard, it stated 'No'. The English judge attempted to communicate with the Belgian judge. The Belgian judge gave information on hearing the child $^{210}$ but did not feel able to give information on hearing the parties. ${ }^{211}$ Unfortunately however it would appear that the judge in the State of refuge cannot even refuse to enforce a judgment accompanied by an Article 42 certificate where the certificate is defective. ${ }^{212}$ In Aguirre Zarraga the CJEU suggested that the only purpose of Article 42(2) is to inform the

\footnotetext{
205 This system might be considered illogical where there is consent because the consent could indicate that the removal was not actually wrongful (despite the fact the requirements in Arts 3 and 5 of the Hague Convention are made out), so habitual residence can change. For further details see the England and Wales report.

${ }^{206}$ Art 10(a). There was also an argument that Art 12(3)(b) applied. Art 12(3)(b) requires that the jurisdiction has been accepted either expressly or in an otherwise unequivocal manner by all the parties to the proceedings at the time the court is seised. Given that the father initially participated in the parental responsibility proceedings in England and Wales in a manner that looked like he accepted the jurisdiction, at the relevant time, then Art 12(3) is applicable. Although he tried to withdraw proceedings at a later stage, it is the date that the court is seised which is relevant.

${ }^{207}$ Art 10(b)(iii), referring to Art 11(7). This only applies where proceedings are not already ongoing, like in the present case. Where custody proceedings are already ongoing in the State of origin there is no need to issue proceedings under Art 11(7).

${ }^{208}$ Art 19(2) Brussels IIa refers to the "same cause of action" in proceedings relating to parental responsibility, see the confirmation of the significance of this point compared to other proceedings covered by the Regulation in Case C-489/14 Av B, judgment of 6 October 2015, ECLI:EU:C:2015:654, para 33.

${ }^{209}$ See above at s C.3(a).

210 The Belgian judge had answered "No" to point 11 ie children were not given an opportunity to be heard, see Re C supra n 193, para 34. However, he explained to Moylan J that he did not hear the child because he considered the child had been given an opportunity to be heard in the Art 13 Hague proceedings through the report of the Cafcass officer which "made the child's position and wishes sufficiently clear" see $\operatorname{Re} C$ ibid para 77.

${ }^{211}$ Re C ibid, para 77.

${ }^{212}$ See Arts 42 and 43. Art 43 indicates that it is the law of the Member State of origin that applies to the rectification of the certificate and that no appeal lies against the issuing of the certificate. It is possible for the underlying Art 11(8) return order to be appealed or to be quashed or suspended due to a change of circumstances, see Beaumont et al, supra n 55, 54 (n 124).
} 
courts in the State of origin of the minimum standards of the contents of the certificate, ${ }^{213}$ but it in no way empowers the court in the State of enforcement to review these conditions. ${ }^{214}$ This renders the certificate virtually pointless if the judgment is enforceable even where the requirements are clearly not met, and in most other cases they are only met superficially. Judges in the State of enforcement should be able to disapply the certificate thereby removing the automatic enforceability of the judgment where the requirements that the Regulation imposes, on the face of the certificate, are clearly not met, and in other cases should be able to review the judgment and certificate on human rights grounds.

\section{F. Conclusion}

The research project has indicated that there are problems with the Article 11(6)-(8) Brussels IIa procedure and that return orders given under Article 11(8) are rarely ever implemented, either through legal enforcement or otherwise. The procedure often gives false hope to leftbehind parents, is only accessible to those who are made aware of the procedure by solicitors or other organisations, and in some countries legal aid is limited so even those aware of the procedure might not be able to utilise it. The procedure also increases animosity between the parents, prolongs the period of instability for the child, and can delay contact between the child and the left-behind parent. Consequently the overall conclusion is that the procedure should be removed from a revised Brussels IIa. Unfortunately it is highly unlikely that this will happen because such a change would have to be approved unanimously by the Council. ${ }^{215}$ Therefore several recommendations have been made with the hope of improving the procedure and creating greater access to justice in these proceedings.

It is recommended that Povse is reversed and the text of the Regulation is followed, in order to ensure that Article 11(8) return orders accompanied by Article 42 certificates are only issued following a full welfare enquiry and not in relation to summary proceedings. Article 11(8) proceedings should be restricted to Hague non-return orders based on Article 13(1)(b). There should also be several changes made to the Article 42 certificate and judgments given under Article 11(8). Judges should be more accountable and should be required to state clearly: 1) what opportunities to be heard were made available to the parties and the child, 2) where the

\footnotetext{
${ }^{213}$ Aguirre Zarraga supra n 58, para 53.

${ }^{214}$ Ibid, para 54.

215 Treaty on the Functioning of the European Union, Art 81(3).
} 
judge considered it was inappropriate to hear the child the reasons for this should be stated in the certificate, 3) how the judge took account of the reasons for and evidence underlying the non-return order. The judgment should not be automatically enforceable in the State of refuge, but should instead be reviewable on human rights grounds. If the judgment and the certificate are reasoned appropriately as per the suggested requirements the judgment should be able to stand up to such a review. Some free legal advice, possibly 30 minutes, should be provided as a minimum requirement to enable parties to be aware of the law in this area and encourage them to participate in proceedings. In relation to Brussels IIa more generally Article 20 should be altered and moved to the chapter on jurisdiction, in order to enable judges to take any protective measures they see suitable and to ensure that such measures are automatically enforceable until the courts in the habitual residence of the child are able to take appropriate measures. There should be suitable mechanisms in place to ensure ongoing contact for the leftbehind parent with the abducted child during proceedings in which the return of an abducted child is being sought, so that their relationship does not break down. A less radical way of ensuring that protective measures and interim access orders can be granted by the courts of the State of refuge in child abduction cases with extra-territorial effects would be to clarify in the text of the revised Regulation that Article 11 of the 1996 Convention applies in intra-EU cases and by clarifying in the recitals to the revised Regulation that these types of protective measures are to be regarded as "urgent" within the EU for the purposes of that requirement in Article 11 of the 1996 Convention. In the context of making a return order for an abducted child the courts of the State of refuge should not only be able to order protective measures for the child but also for abducting parents willing to return to the state of habitual residence with the child (such as protection from violent, potentially violent, or abusive left-behind parents and the removal of criminal proceedings). These protective measures should go beyond what is currently permitted by Regulation No 606/2013. Minimum standards for Central Authorities should be created such as requirements on Member States to provide suitable IT equipment (including video-conferencing), which will assist Central Authorities providing important data, and to have sufficient staff including some that are legally qualified. Member States should also be required to ensure that their enforcement laws in relation to enforcing the return of an abducted child are effective and appropriate for children and that legal aid is provided where a party is unable to pay enforcement fees. 